DOI 10.4467/25439561KSR.19.003.11305

ZBIGNIEW BABIK (D) https://orcid.org/0000-0002-8809-3461

Uniwersytet Jagielloński

Kraków

\title{
„NIEPRAWIDŁOWE” SUBSTYTUCJE GŁOSKOWE W SUBSTRATOWEJ TOPONIMII. NOWE PRZYCZYNKI DO CHRONOLOGII I PRZEBIEGU JĘZYKOWEJ SLAWIZACJI PÓŹNIEJSZEJ SŁOWIAŃSZCZYZNY WSCHODNIEJ ${ }^{1}$
}

\author{
“IRREGULAR" SOUND SUBSTITUTIONS \\ IN THE SUBSTRATE TOPONYMY. \\ NEW CONSTRIBUTION TO THE CHRONOLOGY \\ AND PROCESSING OF THE LINGUISTIC SLAVICIZATION \\ OF THE HISTORICAL SLAVIA ORIENTALIS
}

\begin{abstract}
Streszczenie
Artykuł poświęcony jest zagadnieniu nieoczekiwanych sekwencji fonemów spotykanych niekiedy $\mathrm{w}$ toponimach wschodniosłowiańskich podejrzanych o przejęcie $\mathrm{z}$ wymarłych autochtonicznych przedsłowiańskich języków dorzeczy Prypeci i górnego Dniepru oraz ich okolic, przypuszczalnie spokrewnionych z bałtosłowiańskimi. Przykłady te mogą być traktowane jako naruszające późnoprasłowiańskie prawa głosowe (szumiące kontynuanty ie. palatowelarnych, jak w litewskim, zamiast syczących; druga palatalizacja tylnojęzykowych zamiast oczekiwanej pierwszej; tylnojęzykowe zachowane jako takie przed refleksami wokalizmów *e, *ě czy *b) sugerując, że przedmiotowe nazwy przejęto do wschodniosłowiańskiego z lokalnych substratów językowych po dokonaniu się odpowiednich zmian

1 Niniejszy tekst jest rozbudowaną do postaci artykułu prezentacją przedstawioną w Krakowie na posiedzeniu Komisji Kultury Słowian PAU dnia 18 maja 2018 roku (na zaproszenie tejże Komisji). Szerzej potraktowano w nim niektóre wątki pojawiające się podczas dyskusji nad wystąpieniem.
\end{abstract}

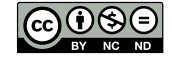


słowiańskich. Najbardziej kontrowersyjne są przykłady braku monoftongizacji dyftongów różnych typów (on, ou itd. przed spółgłoskami), nastręczające problemy związane z fonotaktyką.

Uzyskane wyniki wspierają pogląd części archeologów, zgodnie z którym językowa slawizacja tych terenów (w tym i Wołynia), dawniej uważanych za geograficzny punkt wyjścia słowiańszczyzny nawet przez część językoznawców, była procesem długim i przewlekłym, niezakończonym przed końcem I tys. n.e.

\section{Abstract}

The paper deals with the problem of unexpected phonemic sequences encountered sometimes in East Slavic toponyms suspected of being borrowed from the extinct autochthonous Pre-Slavic languages of the Pripet and Upper Dnieper basins (and their vicinities), supposedly related to Balto-Slavic. These instances can be considered as exceptions to several Late Common Slavic sound laws (hushing spirants continuing IE palatovelars, as in Lithuanian, instead of whistling ones; the second palatalization of velars instead of the expected first one; velars not changed to affricates and / or spirants before the reflexes of the vocalisms *e, * é or

$*_{b}$ ), suggesting that the respective names were borrowed into East Slavic from local linguistic substrates after the sound laws in question had been completed. The most controversial issue are the apparently non-monophthongized diphthongs of various types (on, ou etc. occurring before consonants), which do posit certain phonotactic problems.

The results obtained in the paper support the view, expressed by some archaeologists, that the linguistic Slavicization of these areas (including Volhynia), earlier considered as the geographical point of departure of Slavic even by some linguists, was a long and continuous process which was not completed before the end of the $1^{\text {st }}$ millennium AD.

Słowa kluczowe: Bałtowie dnieprzańscy, początki Słowiańszczyzny wschodniej, substytucje fonetyczne, toponimia substratowa, slawizacja Wschodniej Europy

Keywords: Dnieper Balts, beginnings of the Slavia Orientalis, sound substitutions, substrate toponymy, Slavicization of Eastern Europe

\section{Wprowadzenie}

Widoczny w ostatnich dekadach kierunek ewolucji toponomastyki słowiańskiej można półżartem określić mianem ,zwrotu ku słowiańskiej leksyce apelatywnej”. Narasta bowiem przekonanie, że baza leksykalna nazewnictwa powstającego w dobie średniowiecznej i później nie odbiegała radykalnie od puli wyrazów toponimicznych zachowanych historycznie w leksyce apelatywnej przynajmniej jednego dialektu słowiańskiego. Te przypadki, które wyłamują się z takiej ogólnej reguły, zwykle wykazują przejrzystą strukturę morfemiczną, ułatwiającą rekon- 
strukcję wymarłych apelatywów. Natomiast zasób historycznie wymarłych podstaw leksykalnych, których struktura morfematyczna nie jest już przejrzysta dla slawisty, stanowił - biorąc też pod uwagę ograniczoną z natury rzeczy pojemność zasobów leksykalnych dialektów wczesnosłowiańskich - prawdopodobnie niewielki margines. Przekonanie takie stanowi uboczną konsekwencję stopniowego odchodzenia od koncepcji „wielkiej” Słowiańszczyzny przedhistorycznej, motywowanego przede wszystkim znaczną jednolitością języków słowiańskich u progu ich historii. Wynika z niego konieczność uznania na dzisiejszych ziemiach słowiańskich obecności toponimicznych substratów przedsłowiańskich, chociaż ich przetrwanie uzależnione było od kontaktów między różnojęzycznymi populacjami w dobie slawizacji; w sporach prowadzonych wokół tego problemu, głównie między archeologami i toponomastami, rolę arbitra powoli zaczyna przejmować (archeo)genetyka. Obecność nazw niejasnych, nieanalizowalnych na gruncie historycznych systemów słowiańskich, zaczyna być zatem traktowana jako zjawisko zwyczajne, niedeprecjonujące bynajmniej toponomastyki słowiańskiej i jej metod. $Z$ drugiej zaś strony sama lokalizacja tej czy innej nazwy na historycznym (ze średniowiecznej czy zwłaszcza dopiero późniejszej perspektywy) terytorium słowiańskim przestaje być wystarczającym uzasadnieniem dla podejmowania forsownych prób jej interpretacji rodzimej. Dawniej każda nazwa, niezależnie od stopnia jej skomplikowania, izolacji czy osobliwości na tle systemu słowiańskiego (a także rangi noszącego ją obiektu), była potencjalnie traktowana jako rodzima, analizowana na równi (i podobnymi metodami) z niemotywowaną leksyką apelatywną - pod warunkiem wszakże nieposiadania nawiązań na terenach historycznie niesłowiańskich (przykładem takiej „niedzisiejszej” perspektywy badawczej było np. K. Moszyńskiego potraktowanie nazw głównych rzek Podnieprza - 1957, 167-206). Dziś obranie takiej perspektywy wymaga już wskazania dodatkowych przesłanek, np. przejrzystości struktury, powtarzalności w różnych krajach słowiańskich lub produktywności w nazewnictwie przynajmniej jednej części Słowiańszczyzny.

W badaniach wschodnioeuropejskich warstw nazewniczych już w I połowie XX w. zwrócono uwagę na obecność niesłowiańskiego substratu, który wówczas zwykle określano jako bałtycki. Zasięgiem tej warstwy nazewniczej objęto dorzecza górnego Dniepru, potem też górnych Dźwiny, Łowaci, Oki i Wołgi. Z najważniejszych działań tego okresu należy wymienić prace K. Būgi (zwłaszcza 1923) i M. Vasmera (np. 1932; szczegółowy przegląd historii problemu do lat 60. XX w. można znaleźć w TT 4-16). Zasięg jej próbowano rozszerzyć dalej, m.in. na basen Dniepru środkowego, gdzie jednak starsze warstwy nazewnicze prawdopodobnie zostały „zmyte” przez kolejne fale depopulacyjne, a głównym łącznikiem z warstwami historycznymi pozostały nieliczne makro- i mezohydronimy. Decydujący krok w tym kierunku uczyniono w roku 1962. Praca Toporowa i Trubaczowa 
o hydronimii górnego Podnieprza została uznana za przełomową dla ugruntowania tezy o szerokim, sięgającym właściwie strefy lasostepu zasięgu przedhistorycznych dialektów bałtyckich. Jej ocena po latach i z punktu widzenia innych tradycji onomastycznych jest ambiwalentna, $\mathrm{z}$ jednej bowiem strony odegrała ona decydującą rolę w przełamaniu pewnych dysfunkcjonalnych schematów myślenia o toponimii wschodniosłowiańskiej i historii językowej tego terytorium, a także sposobach analizy (zwrócenie większej uwagi na kwestię formacji nazw), z drugiej stanowi niewątpliwie przykład metodycznego ,anything goes”. Autorzy, opierając się na tej samej bazie źródłowej i wykorzystując zasadniczo ten sam materiał porównawczy, za cel wzięli sobie powiększenie zasobu toponimii traktowanej jako (staro)bałtycka i poszerzenie jej areału. Mogło się to „powieść” jedynie przy znaczącym poluzowaniu rygorów analizy i obniżeniu wiarygodności dokonywanych ustaleń. W książce nie respektuje się podstawowych wymogów, bez których trudno dzisiaj wyobrazić sobie naukowe badania toponomastyczne - brak krytyki źródłowej z prawdziwego zdarzenia, nie rozpoznaje się i nie bada kontekstu onimicznego (ułatwiającego rekonstrukcje wyjściowych brzmień, w hydronimach często zatartych przez derywację sufiksalną), masowo anektuje oczywiste nazwy rodzime na rzecz warstwy substratowej, a fonetyczna strona porównań nazewniczych razi dowolnością. Zabrakło też dokumentacji historycznej, zwykle niewykraczającej poza XIX w. Obaj autorzy stali się rychło ikonami językoznawstwa rosyjskiego, co doprowadziło do sytuacji paradoksalnej - z jednej strony książka nadal przedstawiana jest jako wybitne osiągnięcie toponomastyki słowiańskiej, z drugiej współczesne próby - przez mniej utytułowanych autorów - ścisłego nawiązywania do zaprezentowanych w niej praktyk słusznie spotykają się ze zdecydowanym odrzuceniem już na etapie recenzji wydawniczych.

W okresie późniejszym podejmowano próby poszerzenia areału bałtyckiego w kierunku północnym i wschodnim, przy czym najbardziej aktywny na tym polu był sam Toporow (1972; 1982a; 1982b; 1988; 1989; 1992; 1997). Niestety, w pracach tych, niekiedy wtórnych jedna względem drugiej, zbierających nazwy niejasne ze zwykle odległymi formalnie porównaniami w nazewnictwie krajów bałtyckich oraz grupę oczywistych wschodnioslawizmów bazujących na wspólnej leksyce bałtosłowiańskiej, udział tej ostatniej grupy wzrastał, w niektórych pracach zbliżając się do 50\% (np. 1992: 11 z 23 przykładów). Podobne mieszanie nazw substratowych i oczywistych slawizmów notujemy w operujących hydronimią pracach archeologa W.W. Siedowa (np. 1971a; 1971b).

W badaniach strefy północnej najbardziej zasłużyły się R.A. Agiejewa (1974a; 1974b; 1981; 1985; 2004) i E.M. Katonowa (np. 1973). Obecnie badania prowadzone są głównie w ośrodku nowogrodzkim, dotycząc terenów na północ od Dźwiny i charakteryzując się wyraźnie większym niż dawniej stopniem rzetelności i ostroż- 
ności (por. Васильев 2007; 2008; 2012; 2016). Jednak i tu niektóre nazwy przyszeregowalibyśmy inaczej.

W dotychczasowych badaniach nad substratem wykorzystywano głównie dane hydronimiczne, przede wszystkim według mocno niepełnych wykazów P.L. Masztakowa z I połowy XX w. (np. z całego Podnieprza zebrał on tylko ok. 9 tys. nazw). Rzadko sięgano do ojkonimii, zaś dużych zbiorów nazewnictwa terenowego przed latami 70. XX w. nie było. Począwszy od tego momentu, zaczęły pojawiać się białoruskie i ukraińskie opracowania nazewnictwa terenowego zawierające już po kilkanaście tys. nazywanych obiektów. Przyspieszenie nastąpiło w ostatnich dekadach:

- obwód homelski na Białorusi (1987-1997). Publikowany w periodyku „Беларуская мова” cykl materiałów pod wspólnym tytułem Materiały do stownika hydronimów Homelszczyzny ${ }^{2}$, wbrew niemu obejmujących też wiele nazw obiektów normalnie klasyfikowanych jako „suche” (łąki zalewowe, lasy łęgowe itp.). Nazwy były zbierane przez różnych autorów pod koniec XX w. Wydano materiały z $16^{3}$ spośród 21 powiatów obwodu. Sposób opracowania nie jest jednolity. Niekiedy (zależnie od autora) oznaczono miejsce akcentu i rodzaj gramatyczny nazw, lokalizowanych do poziomu wsi. Część odcinków zawiera domieszaną leksykę apelatywną, co rodzi określone trudności przy ocenie poszczególnych nazw. Ogólnie wspomnianych 16 części zawiera nazwy przeszło 10 tys. obiektów.

- obwód mohylewski na Białorusi (2004). Osobliwy redakcyjnie zbiór bez części wprowadzającej (która mogłaby zawierać bliższe informacje o okolicznościach jego powstania, ostatecznie zepchnięte do notki na stronie wydawniczej) zawiera nazwy terenowe wraz z lokalizacją do poziomu wsi. Nazwy są standaryzowane, oznaczono miejsce akcentu i rodzaj gramatyczny. Zbiór obejmuje może 1/3-1/4 nazewnictwa terenowego obwodu, zawierając poniżej 10 tys. haseł (nazwy maksymalnie kilkunastu tys. obiektów).

- obwody wołyński i rówieński na Ukrainie (2006/2007). Znakomite w aspekcie źródłowym opracowanie oparte na eksploracji prowadzonej przez łuckich studentów. Zawiera standaryzowane (często błędnie lub dowolnie) postacie hasłowe plus oryginalne formy gwarowe (z oznaczonym akcentem, jednak bez informacji o rodzaju gramatycznym i fleksji). Słabą stroną jest „,przeładowanie" artykulików hasłowych fantazjami w postaci eksplikacji nazw podawanych przez informatoró $\mathrm{w}^{4}$, które zastępują naukowe objaśnienia etymo-

\footnotetext{
$2 \mathrm{Nb}$. sam planowany słownik dotąd nie powstał.

3 Powiaty akciabrski, brahiński, buda-koszelewski, chojnicki, czeczerski, jelski, homelski, kalinkowicki, kormski, lelczycki, łojewski, mozyrski, narowlański, petrykowski, wietkowski, żytkowicki. Pokrycie ich terenu nazwami bywa w tych opracowaniach bardzo różne.

4 Kilka przykładów podaję poniżej.
} 
logiczne. Materiał z obw. wołyńskiego zdecydowanie dominuje liczebnie nad materiałem z obw. rówieńskiego (z rozwiązania skrótów wynika, że w dwu powiatach tego obwodu eksploracji w ogóle nie prowadzono).

- obwód czerkaski (2010). Duży i prawdopodobnie starannie opracowany zbiór, do którego nie miałem dostępu. Obejmuje jednak teren poza strefą leśną, pozostając z tej racji mniej interesujący dla zagadnień podejmowanych w niniejszym przyczynku.

- obwód czernihowski (2013). Największe znane mi opracowanie regionalne, obejmujące przeważnie teren strefy lasostepu. Indeks nazw zawiera ok. 26 tys. pozycji (część to zdublowane nazwy tych samych obiektów), co daje pokrycie terenu rzędu 0,8 nazwy na km kw. Zawiera pobieżnie zestandaryzowane postacie (z elementami zjawisk gwarowych, np. akania), jednak bez oznaczenia akcentu i bez informacji o rodzaju gramatycznym i fleksji.

Z czterech co najmniej obwodów Ukrainy posiadamy zatem zbiory nazw o pokryciu terenu $>0,5$ nazwy na km kw. Umożliwiło to podejmowanie „wysokorozdzielczych" analiz toponimii, które bardzo szybko pozwoliły na sformułowanie tezy o znacznych różnicach zachodzących między zasobami nazw niejasnych na poszczególnych obszarach (północno)słowiańskich.

Dla badaczy nazewnictwa słowiańskiego obcy charakter przedwczesnośredniowiecznych warstw toponimii badanego obszaru nie powinien już budzić wątpliwości. Olbrzymi i stale przyrastający zbiór motywacyjnie i (lub) strukturalnie niejasnych toponimów (z którego zaprezentowano poniżej zaledwie niewielki wycinek) wystarczająco dokumentuje znakomite (nawet w stanie nazewnictwa z XX w.) zachowanie starszych, przedsłowiańskich warstw nazewniczych, nie tylko na terenach górnego Podnieprza, ale również na Polesiu. Snuta w slawistyce mityczna opowieść o toponomastycznie protosłowiańskim Polesiu nie wytrzymuje konfrontacji z pełniejszym materiałem nazewniczym tego obszaru, analizowanym zgodnie z wymaganiami współczesnej toponomastyki. Obecnie nie ulega wątpliwości, że cała wschodnioeuropejska strefa leśna pokryta jest szczelnie przedsłowiańskim substratem toponimicznym. Substrat rozrzedza się w strefie leśno-stepowej, gdzie równomiernie zanika i starsza słowiańska warstwa nazewnicza. W części zachodniej (dorzecze górnego i częściowo środkowego Dniepru) pochodzi on z wymarłych języków indoeuropejskich blisko spokrewnionych z bałtosłowiańskimi (czy może nawet bałtyckimi), w części wschodniej Podnieprza niewykluczone są wpływy ugrofińskie. Są to przeważnie nazwy obiektów naturalnych (wód, bagien, lasów), rzadziej miejscowości, ich części czy klasyczne nazwy polne. Ich liczbę w basenach Prypeci, Desny i górnego Dniepru można antycypacyjnie szacować na kilka tysięcy.

Choć większość nazw to nieznane na innych terenach endemity, areał łączy pewna grupa powtarzających się podstaw leksykalnych, a zwłaszcza formacje sufiksalne. 
Najczęstszymi są $-\check{c} a,-\check{z} a,-o \check{z}(a),-i \check{z}(a),-e j a,-v a,-s a,-(o) \check{s} a$. Większość tych formantów nigdy nie łączy się z częściami rdzennymi o postaci typowych słowiańskich struktur prefiksalnych $\left({ }^{*} o r z-,{ }^{*} v y\right.$ - itd.) ani przejrzystymi złożeniami czy przejrzystymi derywatami sufiksalnymi, co wskazuje na ich niefunkcjonowanie jako formantów nazwotwórczych w początkach historii dialektów wschodniosłowiańskich. Stosunkowo częste są wielofonemowe (powyżej trzech sylab) formacje kontynuujące zapewne dawne composita o zupełnie dziś nieprzejrzystej strukturze (uderza częstość spójek innych niż $*_{-o-}$, zwłaszcza $*_{-i-}$ lub $\left.*_{-} u->*_{b}, *_{b}\right)$. Zachodnia granica tego areału biegnie w dorzeczu Bugu / Wieprza (i Sanu?). Tutaj występują ostatnie przykłady nazw z sufiksalnym -cze po tylnojęzykowej (niejasne nazwy jezior Bikcze i Łukcze na Polesiu Lubelskim), nazwy na -iż (np. Ostwiż > Uściwierz) itd.

Mimo stanowiska zajętego przez Toporowa i Trubaczowa nadal utrzymuje się pogląd o istotnej odmienności najstarszych warstw toponimii północnego i południowego dorzecza Prypeci. Szczególnie negatywną rolę w jego utrwaleniu odegrała książka Z. Gołąba (1992), który ograniczone terytorialnie opinie Trubaczowa (1968, 270-272) przeformułował - bez dokonywania analizy porównawczej z nazewnictwem innych terenów - w sensie absolutnym (,jądro archaicznej hydronimii słowiańskiej” w skali ogólno(północno)słowiańskiej). Wynikało to częściowo z ubóstwa wykorzystanych źródeł, częściowo z silnego dążenia różnych środowisk do „wygospodarowania” miejsca dla Słowian we wschodniej Europie. W świetle obecnie dostępnych materiałów, a wbrew obiegowej opinii, także Wołyń jawi się jako jeden $\mathrm{z}$ najbardziej wyrazistych areałów masowego występowania substratu przedsłowiańskiego w toponimii. Inwentarz spotykanych tu baz leksykalnych i formantów nazwotwórczych nie odbiega znacząco od obserwowanego dalej na północnym wschodzie. Stosunek nazw o wątpliwej etymologii słowiańskiej do nazw motywowanych leksyką języków słowiańskich innych niż „macierzysty” (ukraiński) można tu szacować na ok. $30: 1$, a ogólna liczba toponimów sprawiających istotne problemy etymologiczne przenosi 500. Nasycenie nazewnictwa substratem wydaje się tu większe niż na Czernihowszczyźnie i Mohylewszczyźnie, zapewne porównywalne z innymi częściami prawobrzeżnego Polesia (lub większe).

Dla ilustracji zestawmy kilka przykładów najbardziej osobliwych ze slawistycznego punktu widzenia toponimów wołyńskich:

Чепел’óc (część ulicy we wsi Лісняки pow. starowyżewskiego, Арк. II 473), Гадьмате (chutor do wsi Ворокомле pow. lubieszewskiego, Дов1947 63), Ге́в'іл'ша Гйе 'іл'ша (łąka we wsi Літовеж pow. iwaniczewskiego, Арк. I 163), Горо́хвитча (pole we wsi Підгіря w pow. ratnowskim, ib. 187), Яквотень (chutor do wsi Ворокомле, Дов1947 1.c.), Капон'іри (pole we wsi Прилуцьке pow. kiwereckiego, Арк. I 323), Курчуко́н (przys. wsi Торчин w pow. łuckim, ib. 366), Кукувітень (pole i łąka we wsi Бужанка pow. iwaniczewskiego, ib. 393), Окутержа́ 
(przys. do wsi Брониця pow. kamień-kaszyrskiego, ib. II 141), Опчистве́рна (bagno k. wsi Галина Воля pow. starowyżewskiego, ib. 146), Ре́лаўнур (przys. wsi Колона pow. iwacewickiego, ib. 286), Шивціврі (las k. wsi Судче pow. lubieszewskiego, ib. 499), Теле́мбас (rz. k. wsi Старий Чорторийск, ib. 396).

Mimo jednoznacznego dziś (przynajmniej w odniesieniu do górnego Podnieprza) stanowiska toponomastów część środowisk (archeolodzy i historycy z różnych krajów, część laików zainteresowanych wczesną historią w krajach wschodniosłowiańskich) nie potrafi czy nie chce wyciągnąć z nich należnych konsekwencji. W pracach archeologów stale powtarza się motyw niedatowalności ustaleń językoznawczych. Moskiewska historyk A.L. Choroszkiewicz ideologiczne zaplecze takich nasilających się w latach 70. w ZSRR tendencji charakteryzowała następująco $(2000,198)$ :

„Монография 1976 г. была чрезвычайно актуальна тогда, когда еще всерьез говорилось о черняховской и зарубинецкой культурах II в. до н. э. - V в. н. э., как славянских. За попытками удревнить славянство на территории Восточной Европы и расширить его ареал ясно проглядывались ослиные уши „советского патриота”, в 50-70-е годы, да и теперь еще, честно и истово исповедующего мысль, что „родина слонов” находилась и находится попрежнему именно здесь. Работы Русановой внешне были лишены полемической окраски, но по существу все они были направлены против российско-советского ура-патриотизма и против украинского варианта той же идеологии".

W polskim środowisku archeologiczno-historycznym skupionym wokół K. Godłowskiego początkowo powoływano się na prace wyrażającego rozmaite wątpliwości H. Birnbauma (1973) oraz publikującego prace toponomastyczne białoruskiego geografa W.A. Żuczkiewicza (1968a; 1968b), który kwestionował obecność substratu w płd. części Białorusi. W latach 80. silnie dowartościowywano ogłoszony w czasopiśmie etnograficznym wyciąg z pracy magisterskiej znanego później w życiu publicznym K. Miodowicza, w której - nie podejmując (co zresztą zrozumiałe) żadnej własnej analizy materiału - wyłożył on pogląd o nieprzydatności danych toponomastycznych dla rozważań paleoetnicznych (1984, 14, przyp. 23 i 24, 37, 38, 48) ${ }^{5}$. Pod

5 „Dodać można, że pełny zasięg strefy osadnictwa etnicznych Bałtów w I poł. I tys. n.e. nie jest znany”, „Sytuacja etniczna u schyłku starożytności na wschód od Niemna jest nie rozpoznana. Wielu uczonych widziałoby tu plemiona wschodniobałtyckie. Brak na to dowodów”, „«Plemionko» Goljad (traktowane zazwyczaj jako relikt wschodnich Bałtów) mogło przywędrować tu, odłączywszy się z nieznanych powodów od swoich zamieszkałych bardziej na zachód pobratymców”, „Okazuje się, że wyniki analiz Toporova i Trubačeva można interpretować inaczej”, „Dla ustalenia zasięgu danego języka w czasach „,przedhistorycznych” nazwy rzek nie dają wiarygodnego oparcia”, „Tymczasem dowiadujemy się, że uwzględnione przez V.N. Toporova i O.N. Trubačeva hydronimy mogą mieć genezę bałto-słowiańską i pochodzić z czasów poprzedzających wykrystalizowanie się grupy słowiańskiej”, 
taką presją niektórzy językoznawcy reprezentują opcję ,agnostycystyczną"6 twierdząc, że wyniki badań toponomastycznych nie mogą być wykorzystane do rekonstrukcji historii językowej terytorium. Przykładami takiej postawy są liczne prace H. Taborskiej (np. 1991) i niektóre E. Rzetelskiej-Feleszko (np. 1989). W oderwaniu od praktyki badawczej w tej dziedzinie sugeruje się, że toponimia ta reprezentuje w istocie stadium ,bałtosłowiańskie” (w domyśle: organicznie kontynuowane przez języki słowiańskie, Birnbaum 1973, 56) lub, choć obca, mogła zostać przejęta przez język prasłowiański we wcześniejszych jego fazach rozwojowych.

Jednak prowadzone od pewnego czasu badania nad bazą leksykalną słowiańskiej warstwy nazewniczej dorzecza Dniepru wskazują na jej ubogi i silnie przesunięty w kierunku historycznej leksyki wschodniosłowiańskiej charakter. Proporcja między niejasnymi nazwami ważnych obiektów terenowych i nazwami nawiązującymi do słowiańskiej leksyki dialektalnej kształtuje się tu w sposób wyjątkowo niekorzystny. Najbardziej skrajną sytuację obserwujemy na terenie dobrze rozpoznanego nazewniczo obwodu czernihowskiego (którego oś - przypomnijmy - wyznacza bieg dolnej Desny), gdzie mimo ponawianych kwerend nie udało się znaleźć żadnych współczesnych ojkonimów motywowanych słowiańską leksyką „,niemacierzystą" względem ukraińskiej, a wśród anojkonimów warstwa ta jest reprezentowana słabiej niż gdzie indziej7. Toponimia tego obwodu stanowi modelowy przykład

„Do toponomastyki sięgać warto tylko przy braku przekazów pisanych”, „Analizy hydronomiczne w niewielkim stopniu przyczyniają się do wyświetlenia intrygującego nas zagadnienia. Nazwy wodne są z natury swojej bardzo kiepskim materiałem wyjściowym do jakichkolwiek rekonstrukcji paleoetnicznych. W naszym konkretnym przypadku daje się je zinterpretować na różne sposoby".

Do tych połajanek Miodowicza dobrze pasuje użyte przez pewną archeolog w innym kontekście określenie „kłusownictwo w innej dyscyplinie”.

6 Postawę niektórych archeologów, kwestionujących możliwość wykorzystania danych archeologicznych przy rozstrzyganiu dawnych kwestii etnicznych, M. Parczewski nazwał (zapewne ze względu na negatywne konotacje tego terminu w przestrzeni publicznej), ,negacjonizmem” (np. 2002, 186 i inne teksty). Wspomniany wyżej agnostycyzm, zakładający, że rekonstrukcja dawnego krajobrazu językowego powinna być dokonywana przez archeologów i (mimo braku relewantnych źródeł historycznych) historyków, jest zwierciadlanym odbiciem takiej postawy. Nasuwa się zatem pytanie o źródło tak niekonsekwentnego traktowania postaw agnostycystycznych obserwowanych w poszczególnych dyscyplinach. Czyżby tak mocne było przekonanie o poziomie kompetencji własnych i zarazem niskie mniemanie o autorach ujęć konkurencyjnych? Chyba nie chodzi tu bowiem o programowe stanowisko promujące racjonalność poszukiwania wiedzy o języku poza naukowym językoznawstwem.

Skonfrontowany z taką sytuacją toponomasta ma niewielkie pole manewru - może, zgodnie z kierowanym pod jego adresem życzeniem, zwinąć swój kramik, może jednak również - oczywiście po dokonaniu ponownej oceny sytuacji badawczej - zareagować bardziej niż dotąd asertywnie. Diagnoza jest arcyboleśnie prosta - motywowana desperacją środowiskowa odmowa wiedzy.

7 Z tego obwodu mógłbym wskazać nazwy Загана, Лопинецьь (z wariantem Лопунецъь) oraz dwukrotnie powtarzające się kontynuanty etymonu *mozyrj-, którego rzeczywista produktywność na ukraińskim obszarze językowym może jednak okazać się znaczniejsza, wskazując na stosunkowo niedawną obecność apelatywu w areale. 
współczesnej słowiańskiej warstwy nazewniczej o charakterze kolonialnym, zaszczepionej na silnym przedsłowiańskim substracie. Wykonane sondaże wskazują, że dotychczas dostępne materiały toponimiczne z niżowej części Ukrainy (nie analizowałem opracowań karpackich) nie pozwalają na wytworzenie nawet pozoru możliwości konkurowania z ziemiami zachodniosłowiańskimi (w tym środkowymi partiami ziem polskich) pod względem różnorodności dialektalnej leksyki słowiańskiej odbitej w toponimii (w szczególności nie znalazłem w nich żadnych ekskluzywnych zbieżności toponimicznych z leksyką specyficznie południowosłowiańską, nieznaną obu pozostałym grupom języków słowiańskich). Nie potwierdza się również opinia o większym archaizmie odapelatywnej słowiańskiej warstwy nazewniczej północnej czy zachodniej Ukrainy względem Białorusi.

Również analiza formalna nazw podejrzanych o pochodzenie substratowe pozwala niekiedy stwierdzić, że ich slawizacja nastąpiła na zaawansowanych stadiach rozwojowych słowiańszczyzny (pewne elementy ich pierwotnej struktury fonologicznej wykazują traktowanie niezgodne $\mathrm{z}$ obserwowanym w leksyce rodzimej). Zwracano na to uwagę już dawniej (np. TT 240), nie powstała jednak żadna większa synteza tego problemu, a niska wiarygodność spotykanych w opracowaniach rekonstrukcji utrudnia orientację $\mathrm{w}$ rzeczywistym stanie zagadnienia. W niniejszym przyczynku poruszona zostanie kwestia nieprawidłowych z punktu widzenia historii fonetyki słowiańskiej sposobów przejmowania nazw substratowych.

Zakres opracowania obejmuje dorzecze górnego i środkowego Dniepru, część dorzeczy górnej Dźwiny i górnej Oki (zasadniczo w zakresie objętym dołączonymi mapkami) i basen Bugu w granicach Ukrainy i Białorusi. Nie uwzględniono w zasadzie basenów Dniestru, Bohu, Niemna, Donu i dolnego Dniepru. Oprócz wspomnianych czterech dużych źródeł materiału mikrotoponimicznego z terenów Ukrainy i Białorusi (cykl z БМ, Павл., Маг. і Арк.) wykorzystano zbiór МікрБел, encyklopedię wód Białorusi (БКБ) oraz standardowo wykorzystywane niemiecki pięciotomowy słownik hydronimów (WRG I-V), ukraiński zbiór СГУ i monografię hydronimii Oki (Смол.). Wykorzystano ponadto kilka pomniejszych źródeł. Z zakresu ojkonimii podstawę stanowiły sześciotomowy zbiór białoruski (ННПРБ) oraz wykaz miejscowości Ukrainy z 1947 roku (Дов1947; wybór padł na ten wykaz z racji uwzględnienia w nim wielu punktów osadniczych niższego rzędu, zwłaszcza tzw. chutorów).

Do szczegółowej analizy wybrano następujące procesy:

1. Nieprawidłową refleksację dawnych ie. palatowelarnych;

2. Brak oczekiwanych palatalizacji tylnojęzykowych;

3. Brak oczekiwanych monoftongizacji dyftongów (ustnych i nosowych).

O ile pkty 1. i 3. wymagają właściwie niezależnego wyznaczenia praformy (opartego o porównania zewnętrzne), o tyle w pkcie 2. można śmiało „rekonstruować 
wstecz" w oparciu o zapisy i prawa głosowe (w pewnych wypadkach nie ma możliwości zrekonstruowania praformy bez naruszenia słowiańskich praw głosowych).

Procedura badawcza wyglądała następująco. Najpierw wytypowano nazwy zawierające odpowiednie sekwencje, następnie sprawdzono możliwość sformułowania objaśnień rodzimych. Wyeliminowano większość przykładów zawierających formanty nazwotwórcze typowe dla derywatów nazw osobowych. Wykluczenie motywacji apelatywnej jest dzisiaj względnie łatwe, natomiast problemem pozostaje wciąż model derywacyjny - spotykany również w nazewnictwie interesujących nas obszarów - przenoszący nazwy osobowe do toponimii bez derywacji afiksalnej. Homonimicznych antroponimów starano się poszukiwać w dostępnych zbiorach (m.in. Бірыла 1969 і Веселовский 1974), również nazwisk polskich, a także poprzez wyszukiwarki internetowe. Trzeba się jednak liczyć z możliwością, że niektóre ze wstępnie zweryfikowanych i wykorzystanych poniżej przykładów trzeba będzie w przyszłości uznać za pochodne od rzadkich antroponimów wschodniosłowiańskich.

\section{Nieprawidłowe kontynuanty palatowelarnych}

Indoeuropejskie palatowelarne $* \hat{k}, * \hat{g}^{(h)}$ w językach satemowych (a więc i w bałtosłowiańskim) podlegały spirantyzacji. W pierwszym stadium rozwojowym nowe spiranty nie zmieszały się z istniejącymi wcześniej spirantami i stan taki zachował się zasadniczo w litewskim $(\check{s}: s, \check{z}: z)$. W staropruskim, łotewskim i słowiańskim doszło do pomieszania tych dwu szeregów. W wyrazach dawnych litewskiemu $\check{s}$ kontynuującemu ie. $* \hat{k}$ odpowiada słow. $s$, o ile nie podlegało jotacji względnie nie pochodziło z dawnego *ks przed przednią (wówczas mamy regularną korespondencję $\check{s}: \breve{s})$. Korespondencja typu $\check{s}: \check{s}$ jest regularna także w obukierunkowych zapożyczeniach. Spotyka się ją również w porównaniach nazewniczych litewsko-wschodniosłowiańskich (por. mapka 1).

Dawno już zwrócono uwagę (por. TT 5, z dalszą literaturą) na hydronim Берешта (WRG I 148; БКБ 85: Бярэ́шча, dopł. Jessy w basenie Dźwiny), zestawiony z litewskimi hydro- i toponimami na Beržt-, łączonymi współcześnie z gwarowym apelatywem béržta 'brzezina, miejsce porośnięte brzozami' (Vanagas 1981, 62). Tutaj należy chyba także nazwa kanału Бярэ́штань w pow. solihorskim na płn.-zach. Polesiu (БКБ 1.c.; ok. 9 km dł., początek przy wsi Бярозаўка, ujście do Sitni przy wsi Зялёны Бор), będącego zapewne przekształceniem dawnego naturalnego cieku tejże nazwy.

Grupę wschsłow. nazw wodnych na S̆at- (Шацьк, miasteczko w obw. wołyńskim, znane od XV w., Шат, dopływ Uру, Смол. 80, Шать Шача w basenie 


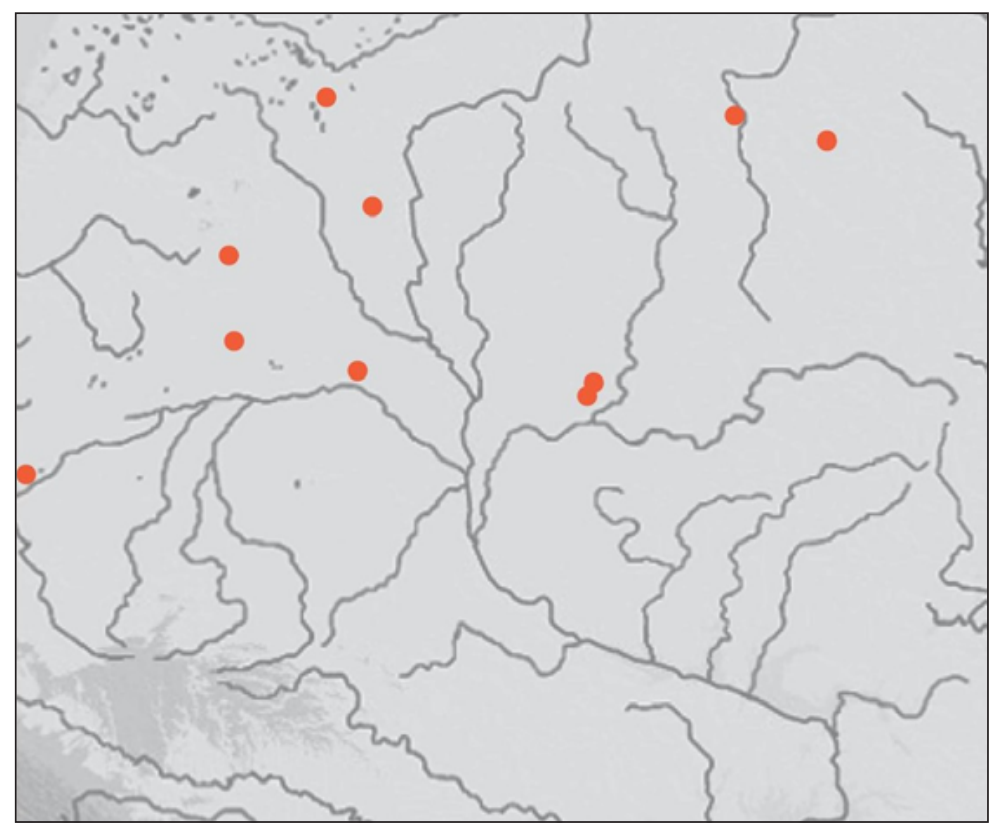

Ptyczy, WRG V 235), od dawna zestawiano z litew. nazwami wodnymi na $\check{S}$ at- (por. TT 213). Lepszym nawiązaniem są jednak onimy na Šet-, uzasadniające wokalizm $a$ w słowiańskim (litew. Šètè itp., por. o nich Vanagas 1981, 326-327, 330). Prapostać *Ksēt- można chyba wykluczyć wobec braku takiego pierwiastka indoeuropejskiego (Pokorny IEW 625).

W artykule z 1971 roku Siedow za bałtyckie uznał nazwy Жижммель (przy źródłach Szoszy na płn. od Moskwy) і Жежммянка Жезмянка (dorzecze Wazuzy; tak już Vasmer 1932, 657), zestawiając je z litew. Žyžmà, Žiežmà (Седов 1971b, 104; por. Vanagas 1981, 402, 405; mimo ogólnie określonej etymologii brak dobrych nawiązań apelatywnych zawierających - $m$-). Obie nazwy położone są jednak daleko na północy (poza zasięgiem dołączonych mapek). Niedawno R. Kozłowa (2013, 127) wskazała ${ }^{8}$ nazwę bagna Жb́́»ммa lokalizowaną w dorzeczu Druci (autorka nieprawdopodobnie traktowała ją jako kontynuującą niepotwierdzone prasłow. *žižbma, związane z *žekti 'palić', anektując cały materiał litew. jako z pochodzenia słowiański).

Zestawienie hydronimu Жии́здрa, nazwy dużego 1. dopł. górnej Oki w obw. kałuskim (Смол. 187-188, 213) z litew. žiegždras 'gruby piasek' (licznie reprezentowanym w hydronimii, por. Vanagas 1981, 401, 405) datuje się z samych początków

8 Za źródłem ukrytym pod nierozwiązanym w artykule skrótem „ПБ”. 
XX w. (Топоров 1988, 47, z dalszą literaturą). W późniejszych badaniach dodano również hydronim Жездрянка z basenu górnej Wołgi (WRG II 9, poza zasięgiem niniejszych mapek). Mimo niezgodności charakteru nagłosowej spółgłoski zaliczam tu także hydronim Ши́з зра obw. homelskiego (БМ ХХ 107; БКБ 408: struga 13 km, dopł. Nienaczy). W nazwach tych uderza stabilność podatnej skądinąd na procesy asymilacyjne sekwencji $\check{S} \ldots z$.

Ojkonim Жукля (d. gub. czernihowska) M. Vasmer (1932, 664, por. TT 9) zestawił z litew. žūkle 'połów ryb'. W późniejszym okresie opublikowano także nazwę wodną Жуклоть, lokalizowaną we wsiach Хлопяники і Данилівка na pograniczu pow. sośnickiego i mieńskiego obw. czernihowskiego (СГУ 199, przekaz z końca lat 30. XVIII w.). Wyraz nie występuje jednak w litew. hydronimii (Vanagas 1981, passim).

Większość materiału zestawionego w TT $(187-188,213)$ nie wytrzymuje krytyki. Nazwę Шедаловка łączyć należy ze wschsłow. antroponimami typu ros. Шедалов, podobnie jak Шишинка і Шарайка. Шемесловка wydaje się graficznym wykolejeniem wariantu Щемелевка, którego pierwotność gwarantuje ojkonim Щемели w gnieździe (WRG V 309). Również nazwy Шалбенка і Щолоня осеniać należy jako wykolejenia graficzne pierwotnego Щолбня, z dobrą motywacją apelatywną (zob. SP II 222, s.v. čl’’pъ). Шуловка znajduje zadowalającą motywację rodzimą. Жога (war. Жеча!), zestawiana z litew. žiogé, o ile w ogóle jest formą realną, daje się objaśnić na gruncie słowiańskim (роr. Козлова 2013, 109, 131). Jako perspektywiczne można pozostawić nazwy Шедра і Шеверка, о ile uda się wskazać bałtyckie odpowiedniki apelatywne lub onomastyczne. Pominięto nadto wszystkie nazwy zawierające $\check{s}, z ̌$ bezpośrednio przed fleksją jako potencjalnie odzwierciedlające jotację (na obecność sufiksów twardotematowych w substracie niezbicie wskazują spotykane w tym areale nazwy na $-(V) z a)$.

\section{Brak oczekiwanych palatalizacji tylnojęzykowych}

W językach słow. tylnojęzykowe $* k,{ }^{*} g,{ }^{*} x$ stojące przed samogłoskami przednimi zostały przekształcone w afrykaty (lub spiranty). W pierwszym stadium (I palatalizacja) powstały, odpowiednio, $\check{c}, \check{z}, \check{s}$, w późniejszym okresie skutkiem monoftongizacji dyftongów powstały nowe samogłoski przednie, które wywołały II palatalizację, wydającą innego typu afrykaty i spiranty. Tej ostatniej podlegała część zapożyczeń (np. * cęta, *cirzky itd.). I palatalizacja, mimo spotykanych opinii odmiennych, jest bez wątpienia przedhistoryczna, II palatalizacja była żywa zapewne jeszcze w VI w., afrykatyzacja nastąpiła później. 
Badanie traktowania tylnojęzykowych w nazewnictwie terenowym wymaga wykonania kilku kroków:

1. wyodrębnienia grupy niejasnych nazw zawierających (na poziomie zapisu gwarowego lub standaryzacji) odpowiednie sekwencje;

2. sprawdzenia w ich zapisach historycznych i gwarowych, czy rekonstrukcja samogłoski jest jednoznaczna (tutaj wykorzystano materiał atlasów gwarowych AУM і ДАБМ).

Wyeliminowano przykłady pochodzące $\mathrm{z}$ obszaru zmiany $y>e$ (Бегета, Гевільша), ale także zawierające nieakcentowane $e$ na obszarze zmiany $e>y$. Wreszcie wyeliminowano sekwencje typu $K i, K y$ (co spowodowało bardzo znaczną redukcję materiału). Pozostawiono tylko jeden przykład posiadający dokładny dublet z $\mathrm{Ci}$ $>$ Су (Кидель:Цылдель).

Jako przykłady wystąpienia palatalizacji drugiej zamiast pierwszej (późniejsza chronologia adaptacji) proponowałbym następujące nazwy (por. mapka 2):

Z Ukrainy:

Це́рем -y, 1. dopł. Słuczy k. Nowogrodu Woł. (WRG V 76; СГУ 597). W 1888 roku nazwę zapisano jako Цr ремъ, jednak inne przekazy nie potwierdzają refleksu *ě. W jednej ze wsi zapisano w 1962 roku postać Щерем. W polskich źródłach występują formy Carem i Cerema (WRG 1.c.). W. Łuczyk $(2014,499)$ wyprowadzał z *Tepeм, przyjmując wpływ białoruski, co na tym obszarze nieprawdopodobne. W. Szulhacz (1998, 60-61) rekonstruował *Čermb, łącząc ze słow. *čerms 'namiot', jednak powtarzanie się nazwy na Białorusi (z innym wprawdzie akcentem) przemawia stanowczo za rekonstrukcją $* C$ -

Цміни, wieś w pow. kołkowskim obw. wołyńskiego (Дов1947 59). <*Сьте̌n-? Zapewne należy tu także ojkonim Цмень -i w pow. stolińskim obw. brzeskiego (ННПРБ-Б 269).

Ци́бля, 1. dopł. Trubieża w Perejasławiu Chmielnickim obw. kijowskiego (lewobrzeże Dniepru, przekazy z XVIII-XX w., zob. WRG V 82; СГУ 598).

Цикля, uroczysko i jar we wsi Озеряни obw. czernihowskiego (Павл. 36). Podobna nazwa Цикла występuje w basenie Tykicza ( $\rightarrow$ Boh), por. СГУ 599.

Ци́мплик, przys. do wsi Торговиця pow. maleszewskiego (Арк. II 465). Barytoneza (a także północna w ramach obwodu geografia) przemawiają jednak przeciwko tatarskiej genezie nazwy i wyodrębnianiu w niej cząstki -lyk.

Цир - $a$, pr. dopł. górnej Prypeci w pow. kamień-kaszyrskim i lubieszewskim (СГУ 599). W. Szulhacz $(1998,63-65)$ rekonstruował prapostać * Čer- $\sim * \check{C} b r-$, zapisy historyczne wskazują jednak na ruchomość samogłoski i $C$-, co nakazuje rekonstruować praformę jako * $\mathrm{Cbr}$ 'b (oksyton), z późniejszym rozwojem w * $\mathrm{Cer}: \mathrm{Cr}$ 'a $>$ *Cer Cer 'á > Cer Cyr'á > Cyr Cyr 'á. Wczesne (rok 1566) zapisy z $i$ mogą także sugerować istnienie dubletu ${ }^{*}$ Cirz. 


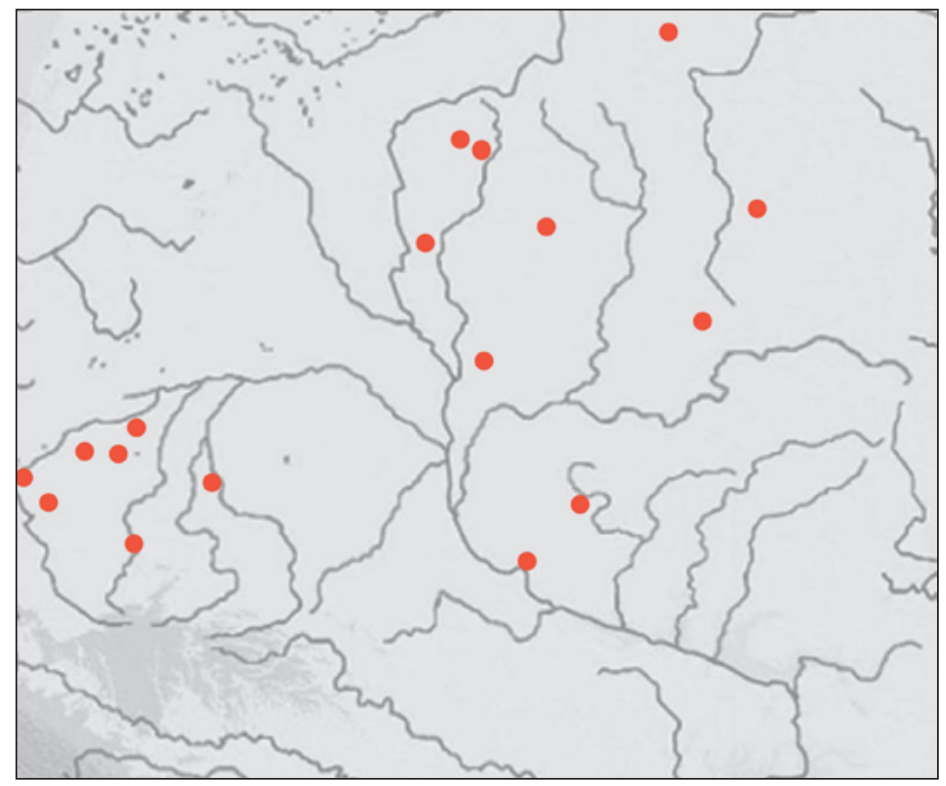

Пові́циво, las k. powiatowej miejscowości Турийськ (Арк. II 230). <*-vе̌ci-.

Пицй́йс'к, las k. wsi Заболоття w pow. lubomlskim (Арк. II 195). Zapewne < *-PVcbj-.

Хйци'a , uroczysko i łąka we wsi Пнівне oraz las w miejscowościach Волиця i Фаринки w pow. kamień-kaszyrskim (Арк. I 454).

Z Białorusi:

Царэ́ м m., zanikła wieś w pow. homelskim obw. homelskiego (ННПРБ-Г 135). Zapewne identyczna $\mathrm{z}$ jednym $\mathrm{z}$ powyższych przykładów, z typowymi białoruskimi zmianami głosowymi $(<*$ Cerém $<*$ Cermъ?).

Пацэ́я, dopł. Rżawki (dziś Касалаўка) w d. pow. bychowskim gub. mohylewskiej (БКБ 285; WRG III 776: Поиея; dziś pow. sławhorodzki obw. mohylewskiego). Prawdopodobnie tożsama genetycznie z postacią Покея na Grzędzie Smoleńsko-Moskiewskiej. Praforma *Potъseja *Potbsěja wydaje się w świetle tego nawiązania nieprawdopodobna. Struktura sufiksu zdaje się wykluczać możliwość wywodu $e$ z * $\check{e}_{2}$. БM XIX 162 daje postać Паце́я ze wsi Залатаміно pow. kormskiego obw. homelskiego, nienależącą jednak do tego gniazda.

Zrezygnowano całkowicie z materiału białoruskiego lokalizowanego między

Prypecią a Berezyną (ze względu na spotykane tam w toponimii ślady cokania).

Z przyległej części Rosji:

Цыдель, dwie rzeki w basenie Ugry w obw. kałuskim (Смол. 40). Prawdopodobny dublet postaci Кидель (p. niżej), por. Топоров (1997, 306, z literaturą). Wa- 
riant Цеделka sugeruje jednak akcent poza pierwszą sylabą, pozostają zatem pewne wątpliwości co do postaci wyjściowej.

Цынь і Цынка, dopł. Woronusy w d. pow. mglińskim d. gub. czernihowskiej (WRG V 84).

Мецна і Мецна М., dwie rz. w dorzeczu Swapy (pow. dmitrowski obw. kurskiego, por. WRG III 265). Zapewne identyczne z kolejną, może punkt wyjścia przeniesienia w dorzecze Zuszy (*Mbcbn-).

Мценск, miasto w obw. tulskim, nad Zuszą i rzeczkami Мецна і Мцыня. W dawnej literaturze (por. TT 225; Rospond 1969, 179; Нерознак 1983, 117) próbowano sprowadzić do prapostaci ${ }^{*} M b d b s n$ - (co thumaczyłoby nieoczekiwane $c<d s \mathrm{~W}$ wariancie * Медcн-), jednak wczesna dokumentacja nazwy miasta (por. Rospond 1.c.; Нерознак 1.c.: najstarszy zapis Мьченьска [gen.] pod datą 1147) wyklucza taki scenariusz - oczekiwany wariant $†$ świadczony, zamiast niego występuje Миен-. Sporadycznie spotyka się zapisy z 4 (może adideacja do тьс̌ь 'miecz'). Wariant Миыня zapewne z Миеня : Миень. Nazwa rzeki może przeniesiona w dorzecze Oki z dorzecza Sejmu (p. wyżej). Wywód z ugrofińskiej nazwy ikry rybiej (Vasmer) nieprawdopodobny zatem semantycznie i formalnie.

Луцня, mały lewy dopływ Wichry (basen Sożu), między 30 i $52 \mathrm{~km}$ od ujścia (https://ru.wikipedia.org/wiki/Buxpa). Prapostać zapewne *Lucbn-, wykluczająca wywód $c<* t s$. Mniej prawdopodobny wywód $\mathrm{z}$ *Lutbsnja. Raczej odrębne od Lutnja (WRG III 146).

Луцейка, mały prawy dopływ Wichry (między 63 i $80 \mathrm{~km}$ od ujścia), zapewne w związku z poprzednim (nieodnotowany w WRG). $<*$ Lucěja?

Jako przykłady braku palatalizacji mimo istnienia warunków fonetycznych proponowałbym nazwy (por. mapka 3):

Z Ukrainy:

Гереба́p -y m., rz. w basenie Słuczy (nazwa ze wsi Моквин pow. kostopolskiego obw. rówieńskiego, СГУ 130), ściślejsza identyfikacja trudna z racji widocznego na dostępnych mapach pokrycia terenu siecią rowów melioracyjnych. W bezpośrednim źródle zapisana z nieoczekiwanym, być może omyłkowym rozdzieleniem (Гере Бар, z archiwum onomastycznego Instytutu Językoznawstwa Ukraińskiej Akademii Nauk), akcent zapewne rekonstruowany. Nienotowana w Aрк. Wskazywałaby najprędzej na praformę * Gerbār-, bez dobrych nawiązań.

Кедива, przys. do wsi Липове obw. czernihowskiego (Павл. 204).

Ке́льпи, bagno k. wsi Устя pow. koreckiego obw. rówieńskiego (Шульгач 1998, 143; zapis dwudziestowieczny). Autor ów sprowadzał nazwę do prapostaci * Kzlpi wiązał ze słow. nazwami 'łabędzia', co nieprawdopodobne $z$ racji dwóch jednoczesnych odstępstw od oczekiwanego rozwoju ( $†$ Koвn-, znanego poza tym na 


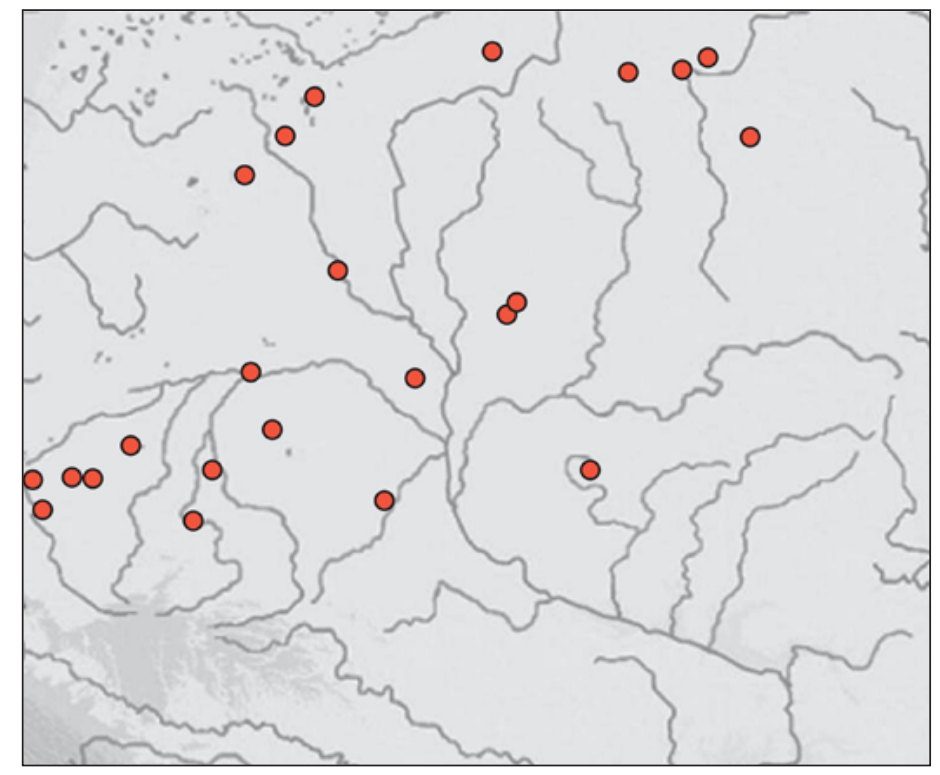

Ukrainie). Prawdopodobnie nazwa związana z kolejną, choć być może wykazująca odmienną adaptację wokalizmu (*Kblbp- vs. *Kelep-).

Ке́лепа, pole we wsi Качин pow. kamień-kaszyrskiego (Арк. I 330). Wg informatora mieszkał tam pan nazwiskiem Kelep, którego to nazwiska nie można niezależnie potwierdzić.

Ке́лтове , bagno k. wsi Гривятки pow. kowelskiego (Арк. I 330).

Кеми́ль, pr. dopł. Zolni w basenie Uborci pow. emilianowskiego obw. żytomierskiego (СГУ 245, zapis dwudziestowieczny).

Kenmáp, łąka k. wsi Поничін pow. włodzimierz-wołyńskiego (Арк. I 330). Przypomina strukturą kilka innych niejasnych nazw z Wołynia (Iкmap, Oбитар).

Кевліч, chutor w pow. radomyskim obw. żytomierskiego (Дов1947 183).

$\boldsymbol{X}$ 'е́нче, pole we wsi Пісочне pow. kowelskiego (Арк. II 440).

Х'ерище, pole we wsi Машів pow. lubomlskiego (Арк. II 440).

Spoza badanego obszaru należy jeszcze wspomnieć o znanym od dawna i nieobjaśnionym przykładzie sekwencji he w hydronimie Гери́ня, nazwie małego prawego dopływu Sukiela9 $(\rightarrow$ Świcza) i ponowionym z niej ojkonimie w dzisiejszym pow.

9 Sam Sukiel (ukr. Су́кіль -елю) w świetle zapisów XV w. brzmiał pierwotnie Sukyl' - a (СГУ 539). Dzisiejsza postać tłumaczy się gwarową zmianą $k y>k i$ oraz odnowieniem tematu przypadków zależnych wg jednego z dostępnych modeli. Nazwa jest ciemna, wydaje się izolowana na gruncie słowiańskim. 
dolińskim obwodu iwanofrankowskiego (por. WRG I 430; СГУ 130; niezobowiązująca moim zdaniem próba objaśnienia z iliryjskiego u Trubaczowa 1968, 251, 252). Z Białorusi:

Ке́рбіцкі, kanał, dopł. Brahinki w pow. łojewskim obw. homelskiego (БКБ 198; БМ XXIII 143: Кербіикая, wsie Вышкаў-Бурыцкая, Руда Бурыцкая). Derywat niezidentyfikowanego onimu na Kerbi-, może w związku z litew. kirba(s) 'grząskie miejsce', niewystępującym jednak (por. Vanagas 1981, passim) w hydronimii (nowszy derywat?).

Kécma, rz. w basenie Dźwiny w pow. lepelskim pow. witebskiego (БКБ 199). Brak przegłosu samogłoski podakcentowej wskazywałby na wokalizm *

Кя́вер m., uroczysko k. wsi Запясочча w pow. turowskim obw. homelskiego (МікрБел 135). <*Kęv-?

Ле́керта -bl, osada w pow. bobrujskim obw. mohylewskiego (ННПРБ-Мг 81).

Мхе́рiна - $a$, dwie wsie w pow. krupkowskim obw. mińskiego (ННПРБ-М 222).

Мя́кестраўка, zanikła osada w pow. łohojskim obw. mińskiego (ННПРБ-М 261). Zapewne derywat na -аўкa od zanikłego onimu.

Pominięto pewną liczbę nazw, w których można wyodrębnić rdzeń *skěp-. Zrezygnowano też np. z mikrotoponimu Керише́ŭ (Арк. I 330: uroczysko w Kamieniu Kaszyrskim), podejrzewanego o nieprzewidywalne wykolejenie z *Perešéj.

Z przyległej części Rosji:

Кердь $\sim$ Керд, dolina i pustkowie przy ujściu Ugry do Oki w obw. kałuskim (Смол. 47). Кирденка, rz. w basenie Sudości (WRG I 583), uznana za bałtycką w TT 190, jest niepewna z racji wariantu Дертенка.

Керпунъ, rz. we wsi Гулевка pow. nowozybkowskiego d. gub. czernihowskiej, dziś terytorium obw. briańskiego (Спис1902 44, nienotowana w WRG). Litew. hydronimy na Kerp- łączono z ludową nazwą jednego z gatunków mchu i fitonimami łotewskimi o innych znaczeniach (Vanagas 1981, 154, s.v. Kérpis).

Kepma, rzeka we wsi Любвин d. pow. nowozybkowskiego d. gub. czernihowskiej, dziś terytorium obw. briańskiego (Спис1902 96, nienotowana w WRG). W hydronimii litewskiej notowano nazwy na Kert-, z zoonimiczną motywacją apelatywną (Vanagas 1981, 154).

Кидель, dopł. Lutnicy w pow. duchowszczyńskim gub. smoleńskiej (WRG II 316). Wg TT 190 (z dalszą literaturą) pokrewne z nieodpowiadającym głosowo litew. Kiduliu up.

Мизге́я Мезге́я, rz., pr. dopł. Upy ( $\rightarrow$ Oka) w obw. tulskim (Смол. 75).

Покея, rz. w basenie Ugry w d. gub. kałuskiej (WRG III 724; nieodnotowana u Smolickiej).

Osobno wyróżniam grupę nazw, gdzie geneza $e$ może być „nieorganiczna” (morfonologiczna, alternująca $\mathrm{z}$ zerem samogłoska wstawna): 
Бакедж' 'í, ulica we wsi Голоби pow. kowelskiego (Арк. I 25). Według informatora od nazwiska rodzinnego, czego nie udało się niezależnie potwierdzić.

Бакет, przys. do wsi Мала Кошелівка obw. czernihowskiego i Бекет, przys. wsi Киселівка (Дов1947 419; Павл. 111, 125).

Бегень , wieś w pow. rówieńskim obw. rówieńskiego (Дов1947 459).

Берегелі, wsie pow. krasyłowskiego i starokonstantynowskiego obw. kamienieckiegо (Дов1947 233, 246).

Брекель, uroczysko we wsi Виблі obw. czernihowskiego (Павл. 103).

Букер, chutor w pow. krasnopolskim obw. sumskiego (Дов1947 529). Nieujęta w monografii Iwanienki (2016).

Ве́кер, wieś w pow. mohylewskim obw. mohylewskiego (ННПРБ-Мг 242).

Вергель, przys. do wsi Шаповалівка obw. czernihowskiego (Павл. 32).

Вярге́ль, las na bagnie k. wsi Чудзін pow. hancewickiego obw. brzeskiego (МікрБел 52).

Кедь, rz. w dorzeczu Ugry, k. wsi Самойловка (Смол. 89).

Keлi, wieś w pow. żytkowickim obw. homelskiego (ННПРБ-Г 181), Кель, wsie obw. mińskiego (ННПРБ-М 200, 201).

Кра́zель, pole we wsi Папарна pow. krupskiego obw. mińskiego (МікрБел 123). Przez autorów nieprzekonująco zestawiane z litew. kragẽlis 'orczyk' (nieodpowiednia semantyka, niezgodność miejsca akcentu).

Огаген, przys. do wsi Ядути obw. czernihowskiego (Павл. 32).

Паге́

Татикетка, dwa dopływy Wopi w d. pow. bielskim d. gub. smoleńskiej (WRG IV 525).

Трохен, dopł. rz. Расен w pow. żytomierskim (WRG IV 617; СГУ 573).

Черкеня, góra na prawym brzegu rz. Syreć (teren Kijowa, por. Железняк 2010, 163-164). Autorka łączy nazwę ze słow. ${ }^{*} c^{c} b r k b ~ * *^{c}$ črka, nie komentuje jednak budowy nazwy. Niewykluczone pierwotniejsze * Черк $(о) н ь \leftarrow{ }^{*} \check{C}_{b} r k(b) n b$.

Do tej kategorii zaliczyłem także nazwę brodu На Цакеркі we wsi Раманішчы (pow. akciabrski obw. homelskiego, БM XXII 200).

\section{Monoftongizacje}

W słowiańskim odziedziczone dyftongi *au, *ai, *ei zostały zmonoftogizowane, odpowiednio, w $u$ (przez stadium *ō), ě oraz $i$. Rozwój jest w całej Słowiańszczyźnie jednolity i zapewne dokonał się w dobie przedhistorycznej. Nie są znane żadne datowane przekazy form słowiańskich zaświadczające stan sprzed monoftongizacji. 
Uproszczone zostały też dyftongi nosowe, co prowadziło do powstania fonetycznych samogłosek nosowych. Moment ich powstania jest trudny do ustalenia, natomiast ostateczna denazalizacja na wschodzie miała miejsce w X w. i bardzo radykalny (w sensie bezwyjątkowości) przebieg. Procesem prawidłowego powstania i zaniku samogłosek nosowych została objęta przynajmniej część zapożyczeń praruskich ze skandynawskiego (np. prarus. ${ }^{*}$ vareg̨ $>$ strus. варягъ).

W wypadku monoftongizacji kluczowe znaczenie ma rekonstrukcja pierwotnej struktury sylabicznej podczas adaptacji nazwy (wykluczenie obecności $* i, * u$ po interesujących nas sekwencjach). W niektórych wypadkach jest to możliwe na podstawie rozpoznania typowej struktury morfologicznej (rekonstrukcja jeru wydłuża nazwę o jedną sylabę, całkowicie zmieniając strukturę etymologiczną). Wyeliminowano jednak wszystkie przykłady, w których jer mógłby wchodzić w skład sufiksu dochodzącego do jednosylabowej podstawy:

Бови(а), dopł. Resty w pow. orszańskim (WRG I 172). Zestawiana w TT 177 ze stprus. Bawse, Bawsiske.

Гройда, podmokła łąka we wsi Moxay̆ pow. łojewskiego obw. homelskiego (Рогалев

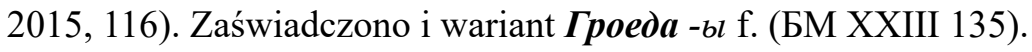

Койра, niezlokalizowana rz. w d. gub. kałuskiej (Смол. 279).

Лаўша́ -b́l, bagniste miejsce k. wsi Коленскі Млынок pow. żytkowickiego obw. homelskiego (БM XVII 163).

Лавща сzy Павша, rz. w basenie Istry, dopływu Moskwy (Смол. 106).

Певжа - $u$, wieś w pow. ostrożeckim obw. rówieńskiego (Дов1947 456). Udokumentowana już w XVII w. (Pluskota 1998). Fonetyka sugeruje pierwotne $* P b v$ (z jerem w kolejnej sylabie).

Лоўзо́ўске (: *Лоўз-) *-ого, bagno k. wsi M. Малешаў pow. żytkowickiego obw. homelskiego (БМ XVII 163: standaryzowane Лаўзо́ўскае -ага).

Скоўдзі -яў, bagno k. wsi Шкава pow. akciabrskiego (БМ ХХІІ 208).

Ровба, chutor do wsi Радча w pow. narodyckim obw. żytomierskiego (Дов1947 179), dziś wieś. Notuje się równobrzmiące nazwisko wschodniosłowiańskie (Бірыла 1969, 352).

Рявжи, jez. we wsi Смяч obw. czernihowskiego (Павл. 235).

Хе́ŭca (БКБ 382) / Пейса -bl (БМ XX 136) / Фейса -bl (БМ XX 143), rz. (kanał) w pow. petrykowskim obw. homelskiego. Nagłosowa samogłoska trudna do rekonstrukcji.

За Моўшай (: * Моуциа), bagno k. wsi Каплічы pow. kalinkowickiego obw. homelskiego (БМ XX 94).

$\mathrm{Z}$ dyftongami nosowymi:

Б'і́нче, przys. do wsi Замчани pow. ratnowskiego (Арк. I 53). Wg informatora nazwany od obfitości wiewiórek (!). 
Бренда, pole w nieoznaczonej wsi na terenie pow. brzeskiego na Białorusi (Арк. I 69).

Домша, dopł. Bystrzycy w d. pow. królewieckim gub. kurskiej (WRG I 627). Por. TT 184.

Домиа, dopł. Pieranki w d. pow. mścisławskim gub. mohylewskiej (WRG I 627).

Гомза, dopł. Rasny w d. pow. dorohobuskim gub. smoleńskiej (WRG I 482). Też Гамза́ -b́l, wieś w pow. swietłohorskim obw. homelskiego (ННПРБ-Г 303).

Го́нча -bl, osada w pow. kliczewskim obw. mohylewskiego (ННПРБ-Мг 202).

Ку́нша (Ліпская), bagno k. wsi Ліпа pow. buda-koszelewskiego obw. homelskiego (БM XVIII 124).

Ломша, pr. dopł. Zapakulki w d. gub. mohylewskiej (WRG III 108). Wg TT 193 do bałt. Lam- oraz nieodpowiadających głosowo litew. Limša, stprus. Lymszen.

Лунца, uroczysko we wsi Спаське w obw. czernihowskim (Павл. 193).

Мо́нча, bagno k. wsi Забалацце pow. mozyrskiego obw. homelskiego (БМ XXII 165) oraz bagno przy wsiach Вярхі, Рамязы, Стар. Высокае pow. jelskiego obw. homelskiego (БM XIX 138).

Минжса, pastwisko we wsi Бакаївка obw. czernihowskiego (Павл. 50).

Прь́́нта -bl, wieś w pow. naroczańskim obw. mińskiego (ННПРБ-М 161).

Пинда, pastwisko і Пиндя, rz. we wsi Стольне w obw. czernihowskim (Павл. 117). Ремза, rz. w basenie Resty ( $\rightarrow$ Soż) w d. pow. czauskim d. gub. mohylewskiej (WRG IV 42).

Си́нда, przys. do wsi Вербень w pow. demidowskim (Арк. II 390). Może od nazwiska (por. derywaty nazwiska Сяндик tamże).

Ше́мра, uroczysko k. wsi Гута-Камінська pow. kamień-kaszyrskiego (Арк. II 498). Wg informatora od żydowskiego antroponimu.

Сенжса, dopł. Ostru ( $\rightarrow$ Soż) w d. pow. rosławskim d. gub. smoleńskiej (WRG IV 233; TT 207 zestawiają ze stprus. Sangele, litew. Sangiališkiai, co wątpliwe). Jeśli z bałt., raczej *Senuž- lub *Senugi-, do bałt. sena- 'stary'.

Сімча, zatoka (Desny?) w miasteczku Десна w obw. czernihowskim (Павл. 64).

Сомиа, bagno w basenie Snowu ( $\rightarrow$ Desna) w d. pow. horodniańskim d. gub. czernihowskiej (WRG IV 352; Павл. 48: bagno we wsi Хотівля) oraz cz. wsi Дроздовиця (Павл. 41).

Свенч -y, podmokła łąka we wsiach Бабічы і Гаёк pow. czeczerskiego obw. homelskiego (БM XVIII 154).

Венча, dopł. Berezyny w d. pow. bobrujskim d. gub. mińskiej (WRG I 283). Wg TT 179 dublet do brzmienia Вяча (inne gniazdo) <*Vetja, co niezobowiązujące.

За́нча -bl, glinianka wypełniona wodą we wsi Лукаўцы pow. jelskiego obw. homelskiego (БM XIX 132).

Proponowane przykłady nieprawidłowej kontynuacji dyftongów (por. mapka 4): 


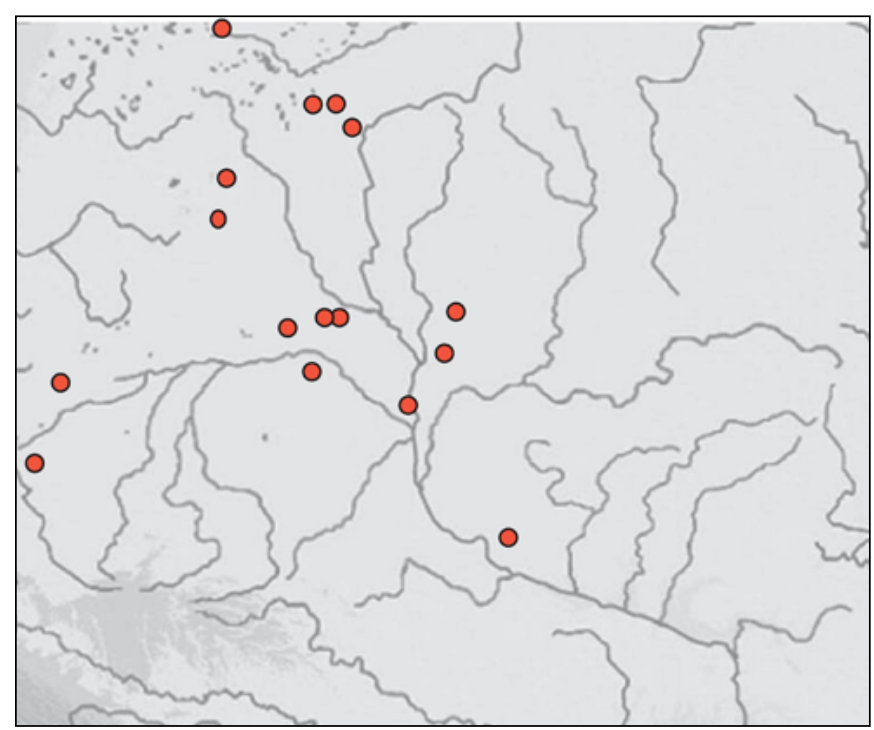

Дараго́йцін - $a$, bagno k. wsi Вынашаўка pow. kormskiego obw. homelskiego (БМ XIX 152).

Довльі́скэ n., uroczysko k. wsi Бялынь Ласіцкі pow. drohiczyńskiego obw. brzeskiego (МікрБел 74).

Кайта́н - $а$ m., bagno k. wsi Лубенікі і Рудня Жураўлёва pow. brahińskiego obw. homelskiego (БM XV 123).

Караго́ўня -i, jez. (starorzecze Dniepru?) k. miejscowości Камарын w pow. brahińskim obw. homelskiego (БM XV 124).

Калб́ўзы , zanikły chutor w pow. wierchniedźwińskim obw. witebskiego (ННПРБ-В 151). Położona w zasadzie na historycznym terytorium letgalskim.

Ковра́й -áю m., trzy rzeki w basenie Dniepru środkowego (por. СГУ 259): 1) 1. dopł. Irkleja w pow. czarnobajewskim obw. czerkaskiego, także warianty Каврай і Ковраец (przekazy z XIX-XXI w.), 2) 1. dopł. odgałęzienia Dniepru poniżej ujścia Supoju (przekazy XIX w.), także Ковраеи (XIII w.), 3) dopł. Supoju w pow. zołotonoskim, dł. $42 \mathrm{~km}$ (przekazy z XIX w.). Prawdopodobnie wszystkie tworzą jedno gniazdo (wskazuje na to także alternowanie z postacią deminutywną). Wczesna dokumentacja wyklucza możliwość rekonstrukcji * Колр-. Zwykle nawiązuje się (np. Лучик 2014, 269) do wątpliwej etymologii Trubaczowa (1968, 254) dzielącej nazwę na Ko-vr-aj i łączącej ją z rdzeniem *vbr- 'wrzeć' (taka struktura nie ma poświadczeń apelatywnych).

Лаўблі -яц̆, bagno k. wsi Млынок pow. mozyrskiego obw. homelskiego (БМ XXII 163). 
Лаўстыцкая -ай, kanał k. wsi Ражанов pow. akciabrskiego obw. homelskiego (БМ XXII 196). Tamże bagno Лаўстыцкія Балоты pl. (wieś Зацішша). Także Лаусттыхуцкая -ай Гліна -bl (wieś Рабкор, ib.).

Мако́y̆за, dopł. Cny w pow. łohojskim obw. mińskiego (БКБ 236; nieujęta w WRG). Нямо́йma -bl, wieś w pow. siennieńskim obw. witebskiego (ННПРБ-В 425). Tamże hydronim, nazwa dopł. Obolanki w basenie Dźwiny (WRG III 396).

Нярэ́йиа, zanikła wieś w pow. siennieńskim obw. witebskiego (ННПРБ-В 433). Tamże hydronim, nazwa dopł. Łuczosy w basenie Dźwiny (WRG III 401).

Пойзер - $a$, łąka w powiatowej miejscowości Акцябрскі obw. homelskiego (БМ XXII 205).

Ре́лаўнур, przys. wsi Колона pow. iwacewickiego (p. wyżej).

Рублейва, dopł. Wiru w d. pow. horodniańskim d. gub. czernihowskiej (WRG IV 102).

Слоўсть (z wariantami Слоўст і Смолость), dopł. Wołmy ( $\rightarrow$ Berezyna) (WRG IV 302; БКБ 339). Przez TT 208 zestawiane z litew. Smalstys, co raczej nieprawdopodobne (zestawiony wariant wydaje się czysto graficzny).

Яўкоп - $a$, bagniste miejsce k. wsi Філіпавічы pow. petrykowskiego obw. homelskiego (БМ XX 147)

Вераво́йша -ьл (Го́рная і Ніюняя), dwie wsie w pow. orszańskim pow. witebskiego (ННПРБ-В 69).

Wyeliminowano nazwy, które można było jednak podejrzewać o kontynuacje sonantów: Ковжи́zа, rz. w basenie Worskli w obw. połtawskim (СГУ 258, dokumentacja od XIX w.), por. słow. kъlz-, Во́вжело n., uroczysko we wsi Дзедаўка pow. żytkowickiego obw. homelskiego (МикрБел 43), por. słow. vblg- oraz Каўчáŭ -я, drobne jeziorko k. wsi Новая Дуброва і Чырвоная Слабада w pow. akciabrskim obw. homelskiego (БМ XXII 193), por. słow. kъlk- $\sim$ kъlč-. Z kolei Лazóŭчbl, podmokła łąka we wsi Асінаўка pow. czeczerskiego obw. homelskiego (БM XVIII 147), mogą być dawną strukturą patronimiczną przekształconą przez zanik interwokalicznego $v$ (*Лаго́вічbl).

Nazwy pozostawione wykazują kilka wyraźnych skupień (m.in. na wschodnim Polesiu, w obw. homelskim). Zjawisko nasila się w dorzeczu Niemna, zaś na historycznym terytorium litewskim w granicach Białorusi jest to normalny sposób adaptacji litewskich dyftongów. Natomiast przykłady takie nie są prawie zupełnie reprezentowane na Wołyniu czy ogólnie w południowym dorzeczu Prypeci.

Zaskakująca okazała się produktywność nazw zakończonych na -овmа ${ }^{10}$ :

${ }^{10}$ Równie liczne nazwy na -овля, wymagające również rzetelnej syntezy, z braku miejsca pozostawiono tu na boku. 
Бяго́ўша -bl, uroczysko k. wsi Асарэвічы і Піркі pow. brahińskiego obw. homelskiego (БM XV 114).

Дороговща, dopł. Biesiedzi w d. pow. suraskim d. gub. czernihowskiej (WRG I 634).

Дубо́вше, przys. do wsi Ушкавиця pow. kobryńskiego obw. brzeskiego na Białorusi (Ark. I 238, s.v. Дубівше).

Kapamóy̆ua, zanikła wieś w pow. lozneńskim obw. witebskiego (ННПРБ-В 303). Котоговиа, 1. dopł. Ressety, pr. dopł. Ugry ( $\rightarrow$ górna Oka) (Смол. 33).

Любовиа, 1. dopł. Szatu ( $\rightarrow$ Upa) w obw. tulskim, z wariantem Любовка (Смол. $80)$.

Либовиа, cz. wsi Бурімка w pow. czernihowskiego (Павл. 52).

Нудовиа (z wariantami Нудовка, Нудоша, Нудо(в)ща), dopływ dolnej Moskwy (Смол. 120-121).

Разавша, dopł. Turočki ( $\rightarrow$ Sejm) w d. pow. rylskim d. gub. kurskiej (WRG IV 8).

Rekonstrukcja *-ov(b)ša, znajdująca nawiązania w toponimii litewskiej (Vanagas 1973, 100, gdzie formanty na -aus-), wydaje się tu bardziej prawdopodobna niż *-lı̌a ${ }^{*}$-blša . Ten ostatni bowiem nie został chyba wyodrębniony na terenach odróżniających obie sekwencje (w szczególności brak go w toponimii polskiej, choć potencjalnie rozwiniętego po zębowych -Tłusza należałoby jeszcze specjalnie poszukać). W hydronimii litewskiej Vanagas początkowo formant -ulšs $(i) a$ wyodrębniał (1973, 201), jednak w słowniku etymologicznym oba przykłady wywiódł od etymonów apelatywnych zawierających -ul- (1981, 171-172, 350, s.vv. Kumulša, Tumulšià). Zasadność wyodrębniania takiego formatywu będzie zatem uzależniona od wymowy materiału mikrotoponimicznego.

Proponowane przykłady nieprawidłowej kontynuacji dyftongów nosowych (por. mapka 5) ${ }^{11}$ :

Бамга́ни, chutor do wsi Журавець pow. łuckiego (Арк. I 27).

Би́ндра, bagno k. wsi Липне w pow. kiwereckim (Арк. I 43).

Ве́ндараж⿻ - $a$, wieś w pow. mohylewskim obw. mohylewskiego (ННПРБ-Мг 243). Вінгу́л- $a$, dopł. Sejmu w pow. królewieckim obw. sumskiego (СГУ 112).

${ }^{11}$ Usunięto z tej listy nazwę Ганджури́ (БM XV 117), pochodzącą zapewne od antroponimu. Nie udało się go zidentyfikować, jednak Biryła $(1969,101)$ notuje zarówno Ганчyра, jak Ганжура. Pominięto też hydronim Ганджа́рка (wsie Вынашаўка і Гарадок pow. kormskiego obw. homelskiego, БM XIX 151).

Ба ри́банда, przysiółki sąsiadujących ze sobą wsi Дожва i Новий Двір w pow. turejskim obw. wołyńskiego (Арк. I 30), to zapewne żartobliwe złożenie z pierwszym członem werbalnym (*beri-). Jeden z informatorów tłumaczył nazwę nawiązaniem do banderowców, drugi zamieszkiwaniem przez samych oszustów (interpretowano zatem wg członu -банда).

Zrezygnowano wreszcie z sekwencji inicjalnych (VNT-) uznając, że samogłoska mogła wykształcić się jako proteza przed pierwotnie nagłosową nosową. 


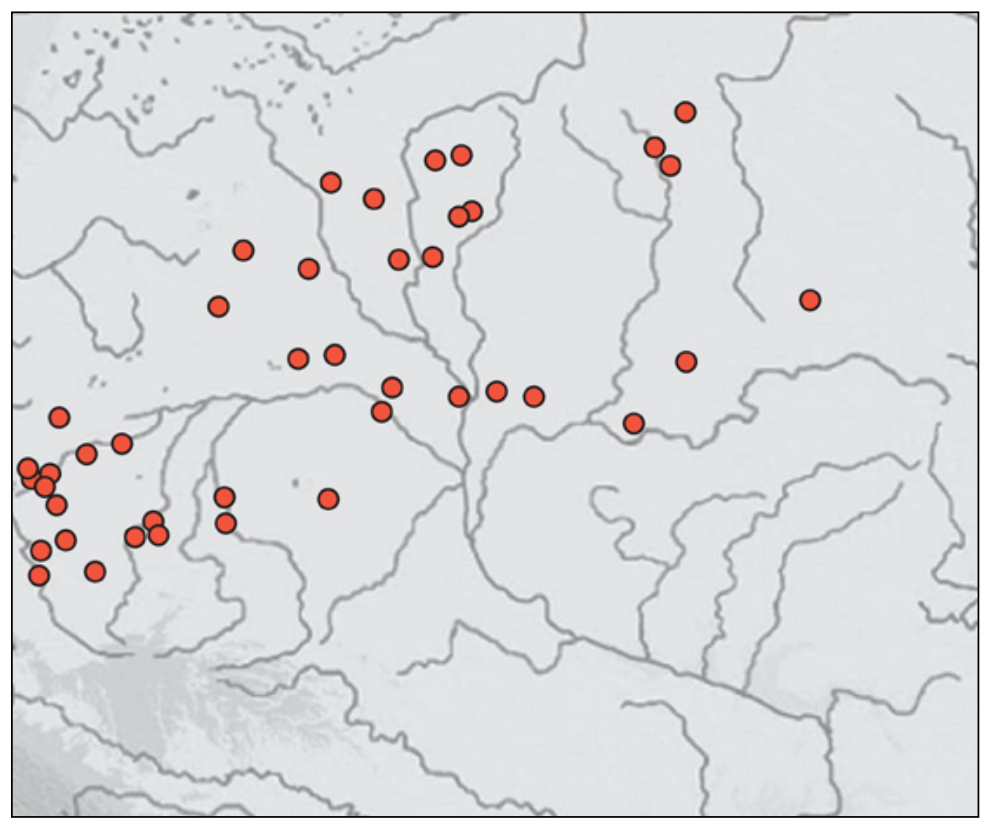

Вандорец Вандарец, dopł. Swapy w d. pow. dmitrowskim d. gub. kurskiej (WRG I 257). Nazwisko Wandor znane jednak w Polsce.

Вандру́жжа - $a$ n., bagno k. wsi Паштовая Глінка w pow. kormskim obw. homelskiego (БM XIX 150).

Вындо́nка f., las k. wsi Аляксеевічы pow. drohiczyńskiego obw. brzeskiego (МікрБел 49).

Вяндзе́љ -á, wieś w pow. puchowickim obw. mińskiego (ННПРБ-М 380) oraz Ве́ндзежс m., mały stawek we wsi Слабада pow. bychowskiego obw. mohylewskiego (Маг. 35).

Ганто́ўля -i, osada w pow. drybińskim obw. mohylewskiego (ННПРБ-Мг 154).

Гонт - $a$ m., grząskie bagno k. wsi Майсееўка pow. buda-koszelewskiego obw. homelskiego (БМ XVIII 118).

Гри́лянд, bagno k. wsi Мочулки pow. turejskiego (Арк. I 194).

Гумри́ча f., dopł. Słuczy w d. pow. nowogród-wołyńskim d. gub. wołyńskiej (WRG I 546; СГУ 161).

Гутанга, dopł. Terebki w d. pow. klimowickim d. gub. czernihowskiej (WRG I 553).

Дземфон -y, ols we wsi Буда Петрыцкая pow. łojewskiego obw. homelskiego (БМ XXIII 136). Niejasna geneza $f$ w nazwie. 
Диме́нто, las i pastwisko k. wsi Деревок pow. lubieszewskiego (Арк. I 220). Wg informatora rzekomo od równobrzmiącego nazwiska (którego nie udało się potwierdzić).

Зансон - $a$, bagno k. wsi Белы Пераезд pow. petrykowskiego obw. homelskiego (БM XX 121). Może derywat od dawnej nazwy gęsi *žans-, z formantem *-anspotykanym na tym terenie.

Илмант, rz. w basenie Bołwy w d. pow. żyzdryńskim d. gub. kałuskiej (WRG II 134).

Ку́́нтыша, zanikła osada pow. słuckiego obw. mińskiego (ННПРБ-М 428).

Камлата, uroczysko we wsi Рогізки obw. czernihowskiego (Павл. 235).

Кринде́лик, cz. wsi Смиків pow. sokalskiego obw. lwowskiego (Арк. I 381).

Кунди́ба, las k. wsi Кадище w pow. kiwereckim (Арк. I 395).

Леянда, rz. w basenie rz. Ремистово (basen Sożu) (WRG II 56).

Ломпадь Лампадь, dopł. Bołwy w d. pow. żyzdryńskim d. gub. kałuskiej (WRG III 108). Wg TT 193 wschodnia (ugrofińska, za Rozwadowskim?). O nie w pełni odpowiadającym głosowo litew. Lampédis por. Vanagas 1981, 179.

Мо́нціск, łąka we wsi Яноўка pow. mścisławskiego (Маг. 135). Wg informatora od nazwiska właściciela znajdującego się tu jakoby majątku ziemskiego. Nazwiska takiego nie udało się potwierdzić. Zapewne derywat od onimu na MónciS-.

На́м'інче, bagno k. wsi Судче pow. lubieszewskiego (Арк. II 117). Ale М'íни'i, uroczysko k. wsi Стара Глуша tegoż powiatu (ib. 92).

Пентрица, dopł. Berezyny w d. pow. ihumeńskim (WRG III 605).

Ромла́вка, przysiółek wsi Мухлин pow. horochowskiego (Арк. II 300).

Рэ́чынг - $a$, bagno k. wsi Веляцін pow. chojnickiego obw. homelskiego (БМ XV 154).

Сіманща -bl, bagno k. wsi Цешкаў pow. narowlańskiego obw. homelskiego (БМ XXII 247).

Са́мбит Со́мбит, las k. wsi Велимче pow. ratnowskiego (Арк. II 315, 359). Tamże uroczysko Сóнбиm.

Симпа́л, jez. w pow. czernihowskim (СГУ 501; Павл. 169: Симполь, jez. we wsi Голубівка).

Синболна, rz. w basenie Letni, 1. dopł. górnej Oki (Смол. 35). Wg Toporowa (1989, 65) z bałt. *Sein-bal-, co wątpliwe.

Скрипу́нс, las k. wsi Typ pow. ratnowskiego (Арк. II 347).

Теле́мбас, rz. we wsi Старий Чорторийськ pow. maniewickiego (Арк. II 396).

Фу́ндаш m., pole we wsi Вілейка pow. dokszyckiego obw. mohylewskiego (МікрБел 243).

Ходумент, dopł. Ceremu w d. pow. nowogród-wołyńskim obw. wołyńskiego (WRG V 44). Szulhacz $(1998,200)$ nieprawdopodobnie próbował sprowadzić nazwę do 
wyjściowego *Odbmotъ (gdyby taka identyfikacja była trafna, należałoby przyjąć polonizm).

Хонт -y m., bagniste miejsce we wsi Ламавічы pow. akciabrskiego obw. homelskiego (БM XXII 214).

Ци́мплик (р. wyżej pod 2.).

Чемлььюж, starsze Чемли́э, wieś w pow. siewskim obw. briańskiego, znana od 1595 roku (https://www.kray32.ru/sevskiy073.html).

Чулі́нда f., bagno k. wsi Ухвала w pow. krupkowskim obw. mohylewskiego (МікрБел 254). Może w związku z litew. kiaule 'świnia', kiauliena 'prosię'.

Шантарá, chutor do wsi Замшани pow. ratnowskiego (Арк. II 494). Wg informatora w chutorze występowało wiele przybudówek do budynków (może skojarzenie z terminem шанта́н). Nazwa ta posiada interesujący dublet z nagłosowym S- w ojkonimii obw. żytomierskiego (Сантарка, wieś w pow. korosteńskim, Дов1947 175).

Штинпа́л ’, bagno w Ratnie (Арк. II 510).

Liczba tych nazw jest zaskakująco duża, a dystrybucja pozwala na wyodrębnienie dwu dużych skupień. Pierwsze pokrywa się z terenem objętym materiałem Arkuszyna oraz zbiorów z БM (i można tłumaczyć je korzystnym stanem badań), natomiast drugie wyodrębnia się na pograniczu obwodów mińskiego, witebskiego i mohylewskiego, gdzie nie można tłumaczyć go szczególnie obfitymi materiałami źródłowymi (większość nazw rekrutuje się ze zbiorów równomiernie pokrywających teren, zwłaszcza hydro- i ojkonimicznych). Może to sugerować, że slawizacja tego terytorium była kontynuowana w X-XII w. Jednocześnie nie znajdujemy większej ilości takich nazw na Podnieprzu środkowym ${ }^{12}$ (w tym na Polesiu żytomierskim) oraz między Sożem i Desną (co wskazywałoby na wcześniejszą, skuteczną slawizację).

12 W szczególności nie wziąłem pod uwagę hydronimu Шáндрa w dorzeczu Rosi (СГУ 617), który również próbowano przedstawiać jako bałtyzm (por. Nalepa 1973, 85, z dalszą literaturą). Nazwa ta posiada realne nawiązania apelatywne w ukraińskim (ECУM VI 375, s.vv. ша́ндра 1. і 2.).

Каланджа́ f., polana w lesie k. wsi Вепрын pow. czerykowskiego obw. mohylewskiego, na której zbudowano wieżę widokową (Маг. 88), wydaje się udźwięcznionym w części końcowej wariantem apelatywu каланчá 'wieża widokowa'. Каланча, rz. we wsi Миколаївка obw. czernihowskiego (Павл. 115), może być przekształceniem lokalnego apelatywu каланчáк 'wybój na drodze, zagłębienie; dolina; wymulisko' (Jurkowski 1971, 168; Черепанова 1984, 91) pod wpływem odpowiedniego leksemu ukraińskiego o znaczeniu 'wieża' (o etymologii zob. Jurkowski 1.c.; inaczej ECУM II 347). 


\section{Varia}

W literaturze sugerowano również inne typy nieprawidłowych substytucji, wymagające jednak dysponowania bardzo pewnymi zestawieniami etymologicznymi. Do najbardziej wiarygodnych należą:

- obce $* \bar{o}>$ słow. $u$ w północnobrus. nazwach na $V_{c-}$ (bałt. ${ }^{*} \overline{o s}-$ 'jesion'), por. Bednarczuk 1996, 121.

- obce *u> słow. $u$ (np. 3ýma, pr. dopł. górnej Oki : łotew. Zuš-, por. Топоров 1990, 373). W materiałach TT zrównań zakładających taką substytucję jest bardzo wiele, zazwyczaj mają one jednak charakter niezobowiązujący.

- obce * $\bar{u}>$ słow. $u$ (np. Cýdocmb, pr. dopł. średniej Desny : litew. Sūd- w toponimii, o którym Smoczyński 1984, 120-126, czy wspomniane wyżej Жукл- < *Žū $k l-)$.

- niewykształcenie się pełnogłosu (przykład poniżej).

Znane są również przykłady wielopostaciowości toponimów substratowych sugerujące kilkakrotne, niezależne przejmowanie tej samej nazwy z języków substratowych. Przykłady pochodzące z obszarów historycznie językowo mieszanych lub pogranicznych nie budzą emocji badawczych (strus. Норова i dzisiejsze Нарва wobec estońskiego Narva; stbrus. Гуя i dzisiejsze Гавья wobec litew. Gaujà - por. Жучкевич 1974, 65; Vanagas 1981, 108-109; ros. nazwy wielkiego jeziora przy źródłach Wołgi Селиге́p ${ }^{13}$, Серегтьрь i starsze * Селижаръ w ojkonimie Селижарово Агеева 2004, 225). Podobne przykłady są znane na innych obszarach (np. bułg. Тънджа (recypient): Тъжа (dopływ) wobec starożytnego Tóvऍo - Дуриданов 1989, 109). Okazuje się jednak, że porównywalne przykłady można zidentyfikować także wewnątrz historycznego areału wschodniosłowiańskiego.

Nazwa rzeki Серёна (pr. dopł. Ugry w obw. kałuskim, por. Смол. 41) stała się podstawą lepiej od niej udokumentowanej historycznie nazwy grodu. W zapisach (zob. Нерознак 1983, 155-156) dominuje postać Серен(V)скъ, jednokrotnie zapisano jednak również postać Шернескъ, różniącą się dwoma szczegółami, zatem odzwierciedlającą zapewne rzeczywistą różnicę językową (Sern- : ̌́s brn-?), być może sprowadzającą się do starszego, przedsłowiańskiego Šern- (o podobnych nazwach litew. Vanagas 1981, 329). Toporow, być może nie znając tego wariantu, wyprowadzał gniazdo z bałtyckiego *Sern- $(1989,54-55)$.

${ }^{13}$ Nazwa jest bez wątpienia związana z nazwą uchodzącej do jeziora rzeki Sorogi. Mamy tu zatem jeszcze inny sposób przejęcia pierwotnie tego samego etymonu, w którym badacze upatrują zwykle ugrofińskiego określenia 'płoci'. 
Strus. ЛогожVскъ (dziś Лагойск, pol. Łohojsk na Białorusi) został zapisany w kronikach pod wczesnymi datami poprzedzającymi zanik wewnętrznych jerów słabych (Rospond 1969, 173; Нерознак 1983, 103). Jednak dzisiejsza postać motywującego potamonimu przeniesionego na osadę Лагóza, Лагазá (ННПРБ-М 254) sugeruje niezależne, przeprowadzone nieco odmiennie zapożyczenie z substratu.

Ба́cя, dopł. Proni (104 km), początkowo (XII w.) była zapisywana jako Басея <*Baseja? (Жучкевич 1974, 18-19, z nieprawdopodobnym objaśnieniem, por. też TT 176), potem także Басcя (<*Basbja?). Zmiana może odzwierciedlać zanik nieakcentowanej samogłoski, dokonany na gruncie białoruskim. W źródłach polskich XVII w. i w polskiej tradycji historycznej (por. Ochmański 1982, mapa na wklejce po s. 176) pojawia się jednak Baszeja (hydronim i ojkonim), trudna do wyjaśnienia jako transpozycja jednolitej postaci starobiałoruskiej. Może zatem i w tym wypadku była w użyciu oboczna postać Бамея?

Nazwa rzeki Połoty stała się podstawą nazwy położonego nad nią Połocka. Występuje ona w wariantach PolotVskъ i PoltVskъ (Нерознак 1983, 139), zatem z i bez przeprowadzonego pełnogłosu - staroskandynawskie Pal(l)teskia (por. Джаксон 2001, 123-124) gwarantuje pierwotność grupy pełnogłosowej, podczas gdy w bezpośrednich, stosunkowo nielicznych przekazach hydronimu grupa pełnogłosowa wydaje się wyłączna.

Inny przykład wielopostaciowości notujemy w nazwie rzeki Proni (dopływ Sożu, $172 \mathrm{~km}$ dł.). Postać Про́ня zwykle thumaczono dotychczas (por. TT 202-203: *Pbrena [sic!]) w oderwaniu od wariantu Prupoj (zob. o nim Жучкевич 1974, 310; była to nazwa Propojska), od którego pochodzi nazwa miejscowa Пропойск (miasto dziś przemianowane na Stawhorod, brus. Славгорад). Wariant ten przetrwał jako Пpanóŭ, określenie wiru przy ujściu Proni do Sożu (czy raczej samego ujścia), mylnie zakwalifikowane jako wyraz pospolity u Jaszkina (1971, 150). Mielibyśmy tu zatem pierwotne *Prop- (czy raczej przedsłowiańskie *Prap-), rozszerzone dwoma różnymi sufiksami nieproduktywnymi $\mathrm{w}$ historycznej toponimii słowiańskiej. Jeśli trafna jest identyfikacja z Propojskiem staroruskiego grodu wymienionego jako Пропошескъ (Rospond 1969, 361; Жучкевич 1.c.), mielibyśmy także trzeci wariant Propoš-. Wyprowadzenie Propojsk z *Propošsk- wydaje się fonetycznie możliwe (interpozycja joty w dobie przed dyspalatalizacją $\check{s}$, por. Łohojsk $<$ Łohożsk), jednak w tym wypadku musielibyśmy przyjmować wyderywowanie hydronimu Propoj $\mathrm{z}$ toponimu. Bardziej prawdopodobna wydaje się dwoistość rozszerzeń -oj- i -oš- lub nawet zachodzące w substracie wahanie fonetyczne $\check{s} \leftrightarrow j$.

Wydaje się, że we wczesnym średniowieczu używano dwu wariantów formalnych nazwy Prypeci. Najpowszechniejsze w zapisach są przekazy wariantu Пpunems (zob. СГУ 446-447; ЕСЛГНПР 111), jednak jednokrotnie odnotowano także Препьтію (kopia XVI w.). W średniowiecznych źródłach polskich i w górnym dorzeczu rzeki 
występują formy wskazujące na prapostać Perepet' < *Perpetb (por. Moszyński 1957, 173-174). Każe to traktować brzmienia Prepetb i Perpetb jako pierwotne, Pripetb jako używaną początkowo w dolnym biegu rzeki innowację zastępującą wariant Prepetb (podciągnięcie pod motywowane struktury rodzime na Pri-). Wymowa alternacji Per-: Pre- nie jest jednoznaczna, podobne wykolejenia, bazujące na przyrodzonej skłonności płynnych ku metatezie, spotyka się bowiem również w rodzimej leksyce słowiańskiej (por. np. alternację *brbv- : *bbrv- 'brewiono').

Oprócz wskazanych wyżej „nieprawidłowych” występują także „prawidłowe” refleksy dawnych sekwencji (Лучёсa: litew. Laukesa i Lankesa, łot. Laucesa itd.). Nie mogą być one jednak wykorzystane do datowania ze względu na możliwość wtórnych substytucji. W szczególności, pozorne refleksy I palatalizacji mogą thumaczyć się substytucją silnie palatalnych tylnojęzykowych substratu przez palatalne (dawniej jotowane) zwarte zębowe (rozwijające się dalej w $\check{c}, \check{z}$ ), por. autor 1998, 186.

Niejasne jest także, jaką postać fonetyczną sekwencje te przybrały w substracie. Przykładem zróżnicowania transpozycji tego samego etymonu w zależności od terytorium może być porównanie Витьба (: Витебск) : Витебеть Вытебеть sugerujące prawdopodobne wahanie $*_{b}:{ }^{*} e$ przy przejmowaniu etymologicznie tej samej struktury (inne przykłady: Келепа: Кельпи, Десна: Цна). Zebrano argumenty przemawiające za rekonstrukcją w substracie spółgłosek o artykulacji wahającej się między szczelinową i zwarto-szczelinową. Znanym faktem jest Чиб(p)uж, nazwa rzeki płynącej przez obw. czernihowski (dopływu Smiacza), por. WRG V 177; TT 228: niejasne) $)^{14}$. Na zachód od jej dolnego biegu po dziś dzień znajduje się duży las, na którego zachodnim krańcu stoi wioska Тупичiв, w której zanotowano mikrotoponim Сібриж (uroczysko, por. Павл. 47). Najprawdopodobniej mamy tu tę samą z pochodzenia nazwę, jednak względy geograficzne sugerują długotrwałe ich funkcjonowanie w izolacji. Nie wyklucza to, że obie mogły zostać zapożyczone niezależnie, w różnych momentach czasowych i na różnych etapach rozwojowych Słowiańszczyzny lub języka substratowego. Dwukrotne przejęcie z elementem spirantycznym zakłada jednak zmianę dokonaną już w substracie. Nośnikiem nazwy mógł być rosnący pomiędzy oboma obiektami las. Wahanie $\check{C}_{-}: S$ - na gruncie lokalnych gwar wschodniosłowiańskich, bez możliwości wyjaśnienia go oczywistymi wpływami paraetymologicznymi ze strony leksyki rodzimej, musielibyśmy potraktować jako nietypową zmianę nieregularną.

${ }^{14}$ СГУ nie notuje tej nazwy, ma natomiast (s. 608) postać Чибра (wieś Хрипівка pow. horodniańskiego obw. czernihowskiego, zapis z końca lat 30. XVIII w.). 


\section{Pytanie o fonotaktykę}

Tylko dwie z omówionych w pktach 1.-3. substytucji (identyfikacja szumiących z szumiącymi przed samogłoskami oraz rozwinięcie się palatalizacji drugiej zamiast oczekiwanej pierwszej) nie nasuwa żadnych zastrzeżeń fonotaktycznych (odpowiednie połączenia istniały / były wytwarzane na dużą skalę w leksyce rodzimej).

Pozostałe nieprawidłowe substytucje naruszałyby teoretycznie ograniczenia fonotaktyczne, w II połowie I tys. n.e. w podstawowej warstwie leksyki słowiańskiej nie występowały bowiem dyftongi „opadające” ani o typie $a u$, ani $a N$, zlikwidowane przez zmiany monoftongizacyjne. Dyftongi typu nosowego były powszechnie adaptowane jako samogłoski nosowe (przykłady w zapożyczeniach z różnych języków). Dyftongi obu typów zostały przywrócone z pewnością w konsekwencji zaniku jerów, który jednak na wschodzie Słowiańszczyzny został wyraźnie opóźniony (aktualnie datuje się go na okres od połowy XII w. na Ukrainie do połowy XIII w. na Rusi północnej). Przesunięcie slawizacji wskazanych wyżej nazw dopiero na XII w. wydaje się ryzykowne i wolelibyśmy go uniknąć. Należy jednak przypomnieć, że sekwencje zawierające niektóre $\mathrm{z}$ tych dyftongów w położeniu przedspółgłoskowym pojawiły się w konsekwencji wykształcenia się $l$ ' epentetycznego (po ou dzięki derywacji dzierżawczej sufiksem -j-, po $m$ również w leksyce niemotywowanej) - co nastąpić mogło jeszcze przed X wiekiem. Stworzyło to przynajmniej precedens strukturalny dla podobnych sekwencji w położeniu przed innymi spółgłoskami. W każdym razie np. obce -aujā czy -aui $\bar{a} \bar{a}$ (podobnie -amjā czy -ami $\bar{a} \bar{a}$ ) mogło być jeszcze przed zanikiem jerów słabych z powodzeniem adaptowane jako -ovl'a (-oml'a). Nosówki zanikły na Rusi w ciągu X w., a więc między przynajmniej końcem X w. a połową XII w. system językowy nie miał dobrego substytutu dla obcych dyftongów nosowych. Niewykluczone zatem, że w tym stadium przejmowanie dyftongów nosowych następowało $\mathrm{z}$ jednoczesnym powstawaniem jerowej samogłoski wstawnej $\left({ }^{*}\right.$ Loməp- $>*$ Lomъp-).

Niewiele wiemy o strukturze szybko ewoluującej specjalnej, motywowanej dźwiękami natury warstwy leksyki słowiańskiej II połowy I tys. n.e. Nie można wykluczyć, że fonetyczne sekwencje dyftongiczne, a także tylnojęzykowe przed przednimi oraz szumiące bezpośrednio przed spółgłoskami twardymi zostały przywrócone dzięki konwencjonalizacji onomatopej itp. W latach 80. N.I. Tołstoj (np. 1987, z dalszą literaturą) zrekonstruował kilka powtarzajacych się w różnych grupach słowiańskich leksemów opartych na rdzeniach geg-, gep-, kek- i kev-, bazujących właśnie na konwencjonalizacjach dźwięków natury, formalnie naruszających jednak I palatalizację tylnojęzykowych. W tej warstwie leksyki mogła tkwić baza artykulacyjna niezbędna dla pozornie nieoczekiwanych substytucji. 
„Urokiem” tego typu badań jest nieusuwalność istniejących trudności; można wprawdzie uniknąć najbardziej niepożądanych implikacji chronologicznych, dokonując np. wstawienia jerów (czyli wcześniejszych samogłosek krótkich) do rekonstruowanej praformy, operacja taka nie jest jednak bezkosztowa - wymaga ona albo rekonstrukcji innego, obcego słowiańszczyźnie (choć ściśle niedatowalnego) prawa głosowego, albo zmienia zupełnie perspektywę etymologiczną, zmuszając do rekonstrukcji formy dłuższej o jedną sylabę, zatem czyniąc tę rekonstrukcję jeszcze bardziej „egzotyczną” z punktu widzenia możliwości analizy slawistycznej.

\section{Wnioski}

Analiza fonologii nazw substratowych z konieczności może operować niewielkim tylko zespołem przykładów zawierających dobrze ugruntowane elementy diagnostyczne. Dla właściwej interpretacji etnojęzykowej warstwy nazewniczej pierwszorzędne znaczenie ma mimo wszystko analiza struktury morfemicznej (seryjne osobliwości sposobów formowania nazw, przy których „punktowe” wykolejenia fonetyczne doby historycznej nie odgrywają istotnej roli) oraz porównania „wielkoprzepustowe", operujące dużymi zbiorami nazw o różnym stopniu niejasności. Jednakże dla językoznawcy historycznego, od wielu pokoleń przyzwyczajanego do wagi (i precyzji) analizy fonologicznej, kryteria fonetyczne - wskazujące w tym przypadku na nieprawidłowy sposób traktowania tworzywa fonologicznego - są, podobnie jak w przypadku zapożyczeń leksykalnych i toponimicznych na innych terenach kolonialnych, z pewnością argumentami najbardziej spektakularnymi i efektownymi.

Analiza starszych warstw toponimii zachodniej peryferii strefy leśnej, choć nie potrafi dać odpowiedzi na pytanie o początki Słowian w dorzeczu Dniepru i dalej, zdecydowanie wspiera rekonstrukcje tej części archeologów (nр. Седов 1970; 1982), którzy zakładają długotrwały charakter procesów kulturowej (i językowej) slawizacji tych ziem. Jedynym realistycznym scenariuszem jest powstanie i kilkuwiekowe przeżywanie się tzw. szachownicy etniczno-językowej, której unifikację i zanik przyspieszyły zapewne dopiero procesy feudalizacyjne i chrystianizacyjne.

Wyniki badań naukowych bywają zaskakujące, nawet brutalne dla wspólnot etnicznych czy narodowych, raczących się (czy raczonych) opowieściami z gatunku „,nowych szat cesarza” pasowanymi do rangi mitów narodowych czy polityk historycznych. Odmowa wiedzy, której towarzyszy budowa alternatywnych narracji przez pasjonatów dawnej historii, jest tutaj zrozumiała, a w naszych, nacechowanych intelektualnym permisywizmem czasach właściwie nie do uniknięcia. Inną miarę stosować winniśmy jednak do środowisk badawczych, od których oczekuje 
się pełniejszej socjalizacji do roli uczestnika gry naukowej i innego, niekoniecznie starożytniczego ukierunkowania indywidualnych i grupowych wzmożeń tożsamościowych. Środowiska partnerskie dla tez niniejszego przyczynku szczęśliwie istnieją i mają się dobrze, jak zaświadcza m.in. poniższy cytat, zaczerpnięty z dostępnego w Internecie cyklu kursów z dziedziny toponomastyki polecanego studentom największego uniwersytetu białoruskiego (Яротов 2011,3):

\begin{abstract}
„К концу VIII века на востоке от нынешних белорусских земель формируется мощный славянский суперэтнос, после чего началось славянское заселение белорусских земель. Оно не носило характера нашествия или массового движения, а, наоборот, было локальным постепенным проникновением славянских племен в пределы территории, заселенной балтскими и другими племенами. Такой процесс заселения в современной исторической литературе получил название инфильтрации, т.е. медленного просачивания. Это перемещение проходило на протяжении столетий, причем были не только распри и войны с местными этносами, но и больше периоды мирного сосуществования. Продолжался сложный исторический процесс борьбы и сближения народов, взаимной ассимиляции и обогащения культур.

Л.Н. Гумилев в книге «Этногенез и биосфера Земли» описывает этот период, который по его убеждению, длился 100-150 лет, и уже к X-XI векам на этих землях стали возникать поселения славянских племен кривичей, дреговичей и радимичей. Славяне в ту эпоху не преобладали численно над местным населением, но являлись более активными, молодым и деятельным этносом, с прогрессивными формами ведения хозяйства".
\end{abstract}

\title{
7. Perspektywy
}

Pomijając analizy banalnych nazw miejscowych i terenowych, jakie z coraz większym powodzeniem podejmowane są w systematycznych syntezach toponimii powstających w krajach wschodniosłowiańskich, najciekawsze poznawczo powinny okazać się próby wzajemnego porównywania warstwy nazw niejasnych, podejrzewanych o pochodzenie substratowe, i starszych warstw nazewnictwa słowiańskiego, zarówno pochodzących od zanikającego z końcem wczesnego średniowiecza imiennictwa rodzimego, jak i odzwierciedlających „niemacierzyste” złoże apelatywne wyrazy znane z innych języków słowiańskich oraz niezachowane nigdzie w postaci apelatywów. Z ukazaniem w taki sposób głęboko peryferycznego (i względnie młodego) charakteru słowiańskiej warstwy nazewniczej Ukrainy (zwłaszcza lewobrzeżnej) nie powinno być żadnych problemów; na Białorusi rzecz przedstawia się nieco odmiennie, zapewne z racji większej stabilności stosunków osadniczych w głębi strefy leśnej w epoce najzupełniej historycznej. 
Od strony substratu, poza standardowymi w takich badaniach katalogowaniem, próbami rekonstrukcji praform, śledzenia geografii wspólnych elementów z wykorzystaniem kartografowania itd., należy zwrócić uwagę na poszerzające się możliwości poszukiwania nawiązań na terenie języków bałtyckich. Szczególne nadzieje należy wiązać z wydawanym obecnie wielotomowym słownikiem nazw terenowych Litwy. Warto także pochylić się nad zaniedbanym problemem rekonstrukcji systemu prefiksów w substracie, który prócz elementów wspólnych dla słowiańskiego i bałtyckiego (np. *po-, *pri-, *per-, *u-, *ne-) musiał też zawierać elementy swoiste. Zwracają np. uwagę osobliwe nazwy na $J a$-, spotykane w głównie południowym dorzeczu Prypeci (Jasiołda, Яжберень, Яполоть, Яквотень), ale i dalej na północnym wschodzie (Ялювань), sugerujące przetrwanie ie. negacji na stopniu zaniku $\left(*_{n-}>*_{\text {in }}>\right.$ słow. ${ }^{*} E_{-}->$wschsłow. $\left.J a-\right)$.

Stosunkowo nowym polem badawczym, otwierającym się przed badaczami w miarę udostępniania pełnowartościowych zapisów gwarowych, może okazać się umiejscowienie akcentu. Pewne obserwacje wskazują na reprodukcję $\mathrm{w}$ tych nazwach systemu akcentowego bliższego litewskiemu, silniej odbiegającego od stanu prasłowiańskiego. Jedną z tych osobliwości jest barytoneza krótkowokalicznych femininów na -a (Мо́жа, До́басна), w zasadzie niespotykana w słowiańskich twardotematowcach. Inną może być niezgodność paradygmatów akcentowych konkretnych nazw i typów morfologicznych. Np. litewskie hydronimy Laukesà i Lankesà wykazują (por. LUEV 86, 88) ruchomy prozodygmat 3b (typu lateralnego, tj. acc. sg. Laũkesa, Lañkesa), gdy Лyчёca ma nieruchomy akcent na samogłosce sufiksalnej, sugerujący zajście w substracie dodatkowego procesu metataktycznego. Na razie obserwacje te dotyczą pojedynczych przykładów, ich uogólnienie stanowi wciąż kwestię przyszłości.

Należy mieć nadzieję na rychłe wypełnienie luk w znajomości nazewnictwa terenowego pogranicza białorusko-ukraińsko-rosyjskiego, zwłaszcza z terenu obwodów żytomierskiego i kijowskiego oraz briańskiego. Przykłady publikacji źródłowych ostatnich dekad, mimo świadomości kontynuacji zarówno pustoszenia, jak i przeobrażającej krajobraz modernizacji wsi wschodniosłowiańskiej i związanych z tym wcześniejszych obaw, skłaniają do optymizmu.

Udział naszych onomastów w badaniach toponimii wschodniosłowiańskiej poza granicami Polski nie był jak dotąd duży. Pomijając starsze prace hydronimiczne (J. Rozwadowski i inni), ograniczał się on do studiów nad ojkonimią, zwykle terenów wschodnich I Rzeczypospolitej (J. Zaleski, T. Pluskota, W. Makarski, A. Czapla, J. Sosnowski) oraz (makro)typami nazwotwórczymi (S. Rospond, H. Borek). Badań nad starszymi warstwami nazewniczymi raczej nie podejmowano, jeśli wyłączyć niektóre prace L. Bednarczuka (np. 1996 czy część tekstów zamieszczonych w jego 2010) i przyczynek S. Kolbuszewskiego (1981). Stan ten powinien ulec zmianie, 
bowiem stająca się coraz wdzięczniejszym polem badawczym toponimia wschodniosłowiańska daje autentyczne poczucie pionierskiej pracy z dostępnym masowo materiałem świeżym, oryginalnym i dotąd niebadanym. Czynnikiem zniechęcającym są tu niewątpliwie narastające trudności z publikacją tekstów większych objętości, są one jednak do przezwyciężenia. Nie widać zatem istotnych powodów, byśmy w tych badaniach - ważnych przecież także z naszej, polskiej perspektywy krytycznie i twórczo nie uczestniczyli, nadrabiając dekady zaniedbań i zaniechań.

\section{Literatura}

Bednarczuk L., Ze studiów nad hydronimia Wielkiego Księstwa Litewskiego, [w:] Hydronimia stowiańska II. Materiaty z międzynarodowej konferencji hydronimicznej (Mogilany, 20-24 IX 1994 r.), Kraków, IJP PAN, 1996, ss. 117-135.

Bednarczuk L., Językowy obraz Wielkiego Księstwa Litewskiego. Millennium Lithuaniae MIX-MMIX, Kraków, Lexis, 2010, 312 ss.

Birnbaum H., O możliwości odtworzenia pierwotnego stanu języka prasłowiańskiego za pomoca rekonstrukcji wewnętrznej i metody porównawczej (kilka uwag o stosunku różnych podejść), [w:] American Contributions to the Seventh International Congress of Slavists, 1, Linguistics and Poetics, the Hague-Paris, Mouton, 1973, ss. 33-58.

Būga K., Upiu vardu studijos ir aiščiu bei slavėnu senovè, „Tauta ir Žodis” 1923, 1, ss. 1-44.

Gołąb Z., The Origins of the Slavs. A Linguist's View, Columbus, Ohio, Slavica Publishers, 1992, 454 ss.

Jurkowski M., Ukraińska terminologia hydrograficzna, Wrocław-Warszawa-Kraków-Gdańsk, Ossolineum, 1971, 240 ss.

Kolbuszewski S.F., Hydronimy battyckie obszaru Pskowszczyzny i Nowogrodczyzny, „Sprawozdania Poznańskiego Towarzystwa Przyjaciół Nauk. Wydział Filologiczno-Filozoficzny" 1981, 97-99, ss. 259-261.

LUEV - Lietuvos TSR upiu ir ežeru vardynas, Vilnius, Valstybinè politinès ir mokslinès literatūros leidykla, 1963, 228 ss.

Miodowicz K., Wspótczesne koncepcje lokalizacji pierwotnych siedzib Słowian. Dane językoznawcze, ,Zeszyty Naukowe Uniwersytetu Jagiellońskiego” 722 = „Prace Etnograficzne” 1984, 19, ss. 7-49.

Moszyński K., Pierwotny zasiag języka prasłowiańskiego, Wrocław-Kraków, Ossolineum, 1957, 332 ss.

Nalepa J., Miejsce uformowania się Prasłowiańszczyzny, „Slavica Lundensia” 1973, 1, ss. 55-112. 
Ochmański J., Historia Litwy [2. wyd.], Wrocław-Warszawa-Kraków-GdańskŁódź, Ossolineum, 1982, 416 ss.

Parczewski M., Stan dyskusji archeologów polskich nad etnogeneza Słowian, [w:] Z polskich studiów slawistycznych. Seria X. Językoznawstwo, Warszawa, Komitet Słowianoznawstwa PAN, 2002, ss. 183-189.

Pluskota T., Nazwy miejscowe ziem ruskich Rzeczypospolitej XVI-XVIII w. Toponimia Ukrainy i pogranicza polsko-ruskiego, Bydgoszcz, Wydawnictwo Uczelniane WSP, 1998, 382 ss.

Pokorny IEW - J. Pokorny, Indogermanisches etymologisches Wörterbuch, BernMünchen, Francke Verlag, 1959, 1184 ss.

Rospond S., Stowiańskie nazwy geograficzne z sufiksem *-bsk-, Wrocław-WarszawaKraków, Ossolineum, 1969, 434 ss.

Rzetelska-Feleszko E., Perspektywy badań nad przedstowiańskimi nazwami rzecznymi na obszarze Polski, [w:] Hydronimia stowiańska. Materiaty z IX konferencji Komisji Onomastyki Stowiańskiej przy Międzynarodowym Komitecie Slawistów (Mogilany, 16-18 IX 1986 r.), Wrocław-Warszawa-Kraków-Gdańsk-Lódź, Ossolineum, 1989, ss. 99-107.

SP II - Słownik prasłowiański. II. C-Davbnota, Wrocław-Warszawa-KrakówGdańsk, Ossolineum, 1976, 368 ss.

Popowska-Taborska H., Wczesne dzieje Stowian w świetle ich języka, Wrocław, Ossolineum, 1991, 176 ss.

Smoczyński W., Pochodzenie litewskiej nazwy miejscowej Pilsūdai (pol. Piłsudy), „Onomastica” 1982, 29, ss. 115-126.

Vanagas A., Lietuvos TSR hidronimu daryba, Vilnius, Mintis, 1970, 428 ss.

Vanagas A., Lietuviu hidronimu etimologinis žodynas, Vilnius, Mokslas, 1981, 408 ss. Vasmer M., Beiträge zur historischen Völkerkunde Osteuropas. I. Die Ostgrenze der baltischen Stämme, "Sitzungsberichte der preussischen Akademie der Wissenschaften. Philosophisch-historische Klasse", Berlin, 1932, ss. 637-666.

WRG - Wörterbuch der russischen Gewässernamen, I-V, Berlin-Wiesbaden, Harrassowitz, 1961-1969.

Агеева Р.А., Гидронимия псковских и новгородских (Шелонская и Деревская пятины) земель в свете истории заселения края, Москва, [а.д.Д.], 1974, 20 ss. Агеева Р.А., Субстратная гидронимия западной части Калининской области (в границах исторической Деревской пятины), [w:] Топонимия Центральной России, Москва, Мысль, 1974, ss. 104-111.

Агеева Р.А., Гидронимия балтского происхождения на территории псковских и новгородских земель, [w:] Этнографические и лингвистические аспекты этнической истории балтов, Рига, Зинатне, 1980, ss. 147-152. 
Агеева Р.А., Происхождение имен рек и озер, Москва, Наука, 1985, 144 ss.

Агеева Р.А., Гидронимия русского Северо-Запада как источник культурно-исторической информации, Москва, Эдиториал УРСС, 2004, 256 ss.

Арк. - Г.Л. Аркушин, Словник мікротопонімів і мікрогідронімів північно-західної Украӥни та суміжних земель. I-II, Луцьк, Вежа, 2006-2007, 438 i 536 ss.

АУМ I - Атлас украӥнскої мови. I. Полісся, середня Наддніпрянщчина і суміжні землі, Київ, Наукова думка, 1984.

АУМ II - Атлас украӥнскої мови. II. Волинь, Наддністряншина, Закарпаття і суміжні землі, Київ, Наукова думка, 1988.

Бабик 3., Предполагаемые рефлексы позднепраславянских фонетических изменений в субстратной топонимии лесной зоны Восточной Европь, [w:] Prasłowiańszczyzna i jej rozpad, Warszawa, Energeia, 1998, ss. 177-192.

Бірыла М.В., Беларуская антрапанімія. 2. Прозвішчы, утвораныя ад апелятылуцнай лексікі, Мінск, Навука і тэхніка, 1969, 508 ss.

БКБ - Блакітная кніга Беларусі. Энцылкапедыя, Мінск, Беларуская Энцыклапедыя, 1994, 416 ss.

БМ - „Беларуская мова”, Мінск [periodyk].

Васильев В.Л., Древнебалтийская топонимия в регионе Новгородской земли, [w:] Новгород и новгородская земля. История и археология, Великий Новгород, Новгородский государственный объединенный музей-заповедник, 2007, ss. 271-285.

Васильев В.Л., О проблеме древнебалтийского топонимического наследия на русском Северо-Западе, „Вопросы языкознания” 2008, 3, ss. 76-94.

Васильев В.Л., Славянские топонимические древности Новгородской земли, Москва, Рукописные памятники Древней Руси, 2012, 816 ss.

Васильев В.Л., Проблематика изучения гидронимии балтиского происхождения на территории России, „Linguistica” 2016, 55, ss. 173-186.

Веселовский С.Б., Ономастикон. Древнерусские имена, отчества, фамилии, Москва, Наука, 1974, 382 ss.

Гаврилова Т.О., Денисенко 3.М., Словник мікротопонімї Черкащини, Черкаси, Ю. Чабаненко, 2010, 494 ss.

ДАБМ - Дьялекталагічны атлас беларускай мовы, Мінск, Выдавецтва Акадэміі навук БССР, 1963.

Джаксон T.H., Austr í görđum. Древнерусские топонимы в древнескандинавских источниках, Москва, Языки славянской культуры, 2001, 208 ss.

Дов1947 - Українська РСР. Адміністративно-територіальний поділ на 1 вересня 1946 року, Київ, Українське видавництво політичної літератури, 1947, 1064 ss.

Железняк I.M., Київський топонімікон, Київ, Кий, 2014, 224 ss. 
Жучкевич В.А., Топонимика Белоруссии, Минск, Наука и техника, 1968, 182 ss. Жучкевич В.А., К вопросу об участии балтов в этногенезе белорусов, „Советская этнография" 1968, 1, ss. 107-113.

Жучкевич В.А., Краткий топонимический словарь Белоруссии, Минск, Издательство БГУ, 1974, 448 ss.

ЕСЛГНПР - Етимологічний словник літописних географічних назв Південної Руси, Київ, Наукова думка, 1985, 258 ss.

ЕСУМ II - Етимологічний словник українскої мови. ІІ. Д-Копці, Київ, Наукова думка, 1985, 572 ss.

ЕСУМ VI - Етимологічний словник українскої мови. VI. У-Я, Київ, Наукова думка, 2012, 568 ss.

Іваненко О.В., Назви поселень Сумщини. Історико-етимологічний словнік, Київ, НАН України, 2016, 330 ss.

Катонова Е.М., Некоторые балтийские гидронимы бассейна Западной Двины на территории Белоруссии, „Latvijas TSR Zinātnu Akademijas Vēstis” 1973, 4, ss. 81-87.

Козлова Р.М., Отражение аблаута в славянской ономастике, Студії з ономастики та етимологіï, Київ, 2013, ss. 108-142.

Лучик В.В., Етимологічний словник топонімів Украӥни. 3700 географічних назв, Київ, Академія, 2014, 544 ss.

Маг. - Слоўнік мікратапонімаў Масілёушчыныь, Магілёў, МДУ, 2004, 208 ss.

МікрБел - Мікратапанімія Беларусі. Матэрыялы, Мінск, Навука і тэхніка, 1974, 328 ss.

Нерознак В.П., Названия древнерусских городов, Москва, Наука, 1983, 208 ss. ННПРБ-Б - Назвы населеных пунктаў Рэспублікі Беларусь. Нарматыўны даведнік. Брэсикая вобласиь, Мінск, Тэхналогія, 2010, 320 ss.

ННПРБ-В - Назвы населеных пунктаў Рэспублікі Беларусь. Нарматыўны даведнік. Вічебская вобласиь, Мінск, Тэхналогія, 2009, 670 ss.

ННПРБ-Г - Назвы населеных пунктаў Рэспублікі Беларусь. Нарматыўны даведнік. Гомельская вобласиь, Мінск, Тэхналогія, 2006, 382 ss.

ННПРБ-М - Назвы населеных пунктаў Рэспублікі Беларусь. Нарматыўны даведнік. Мінская вобласиь, Мінск, Тэхналогія, 2003, 606 ss.

ННПРБ-Мг - Назвы населеных пунктай Рэспублікі Беларусь. Нарматыууны даведнік. Магілёусская вобласиь, Мінск, Тэхналогія, 2007, 408 ss.

Павл. - С. Павленко, Мікротопоніми Чернігово-Сіверщини, Чернігів, ПВК Десна, 2013, 600 ss.

Рогалев А.Ф., Топонимия Беларуси. Гомелская область. Лоевский район, Гомель, ГГУ, 2015, 318 ss.

СГУ - Словник гідронімів України, Київ, Наукова думка, 1979, 782 ss. 
Седов В.В., Славяне Верхнего Поднепровья и Подвинья, Москва, Наука, 1970, 200 ss.

Седов В.В., Гидронимия голяди, [w:] Питання гідроніміки, Київ, 1971, ss. 131-137.

Седов В.В., Балтская гидронимика Волго-Окского междуречья, [w:] Древнее поселение в Подмосковье, Москва, 1971, ss. 108-113.

Седов В.В., Восточные славяне в VI-XIII вв., Москва, Наука, 1982, 328 ss.

Смол. - Г.П. Смолицкая, Гидронимия бассейна Оки. Список рек и озер, Москва, Наука, 1976, 404 ss.

Спис1902 - Списокъ населенныхъ мъьстъ Черниговской губерніи, имтющихъ не менъе 10 жителей, по даннымъ за 1901 годъ, Черниговъ, Тип. губ. правленія, 1902, $188 \mathrm{ss.}$

Толстой Н.И., О непоследовательности первой палатализащии задненебныхх согласных в славянских языках. III, [w:] Slawistyczne studia językoznawcze, Wrocław-Warszawa-Kraków-Gdańsk-Łódź, Ossolineum, 1987, ss. 407-410.

Топоров В.Н., Baltica Подмосковья, [w:] Балто-славянский сборник, Москва, 1972, ss. 217-280.

Топоров В.Н., Древняя Москва в балтийской перспективе, „Балто-славянские исследования 1981" 1982, ss. 3-81.

Топоров В.Н., Балтийский горизонт древней Москвы, „Acta Baltico-Slavica” 1982, 14, ss. 259-272.

Топоров В.Н., Балтийский элемент в гидронимии Поочья. I. А. Верхнее левобережное Поочье, „Балто-славянские исследования 1986” 1988, ss. 154-177.

Топоров В.Н., Балтийский элемент в гидронимии Поочья. II, „Балто-славянские исследования 1987” 1989, ss. 47-69.

Топоров В.Н., Из балтийской ареальной гидронимии. К латгальско-восточнославянским языковым связям, [w:] Batto-stowiańskie związi językowe, Wrocław-Warszawa-Kraków, 1990, ss. 365-380.

Топоров В.Н., О балтийской гидронимии Верхнего Подонья, „Linguistica Baltica", 1992, 1, ss. 225-240.

Топоров В.Н., Балтийский элемент в гидронимии Поочья. III, I. А. Верхнее левобережное Поочье. I. Левые притоки Оки, „Балто-славянские исследования 1988-1996" 1997, ss. 276-310.

Трубачев О.Н., Названия рек правобережной Украины. Этимология, словообразование, этническая интерпретация, Москва, Наука, 1968, 292 ss.

ТТ - В.Н. Топоров, О.Н. Трубачев, Лингвистический анализ гидронимов Верхнего Поднепровья, Москва, Наука, 1962, 272 ss.

Хорошкевич А.Л., Судьба - археология. Исследователи славянской истории Ирина Петровна Русанова и Борис Анисимович Тимощук, „Slavia Antiqua” 2000, 41, ss. 191-210. 
Черепанова Е.А., Народная географическая терминология Черниговско-Сумского Полесья, Сумы, Сумский ГПИ, 1984, 276 ss.

Шульгач В.П., Праслов'янський гідронімний фонд (фрагмент реконструкції), Київ, НАН України, 1998, 382 ss.

Яротов А.Е., Топонимика Беларуси. Курс лекиий, Минск, БГУ, 2011, 43 ss.

Яшкін І.Я., Беларускія геаграфічныя назвы. Тапаграфія, гідралогія, Мінск, Навука і тэхніка, 1971, 256 ss.

\section{References}

Bednarczuk L., Ze studiów nad hydronimiq Wielkiego Księstwa Litewskiego [From the investigation of the hydronomy of the former Grand Duchy of Lithuania], [in:] Hydronimia stowiańska II. Materiaty z międzynarodowej konferencji hydronimicznej (Mogilany, 20-24 IX 1994 r.) [Slavic hydronomy 2. Materials from the International Conference on hydronomy (Mogilany, September the $20^{\text {th }}-24^{\text {th }}$, 1994)], Kraków, IJP PAN, 1996, pp. 117-135.

Bednarczuk L., Językowy obraz Wielkiego Księstwa Litewskiego. Millennium Lithuaniae MIX-MMIX [Linguistic picture of the Grand Duchy of Lithuania], Kraków, Lexis, 2010, $312 \mathrm{pp}$.

Birnbaum H., O możliwości odtworzenia pierwotnego stanu języka prasłowiańskiego za pomoca rekonstrukcji wewnętrznej i metody porównawczej (kilka uwag o stosunku różnych podejść) [On the possibility of recreating the primitive form of Proto-Slavic using both the internal reconstruction method and the comparative one. Some remarks on the relationship between different approaches], [in:] American Contributions to the Seventh International Congress of Slavists, 1, Linguistics and Poetics, the Hague-Paris, Mouton, 1973, pp. 33-58.

Būga K., Upiu vardu studijos ir aiščiu bei slavènu senove [Study of river names and the prehistory of the Balts and Slavs], „Tauta ir Žodis” 1923, 1, pp. 1-44.

Gołąb Z., The origins of the Slavs. A linguist's view, Columbus, Ohio, Slavica Publishers, 1992, $454 \mathrm{pp}$.

Jurkowski M., Ukraińska terminologia hydrograficzna [Hydrographic terminology of Ukrainian], Wrocław-Warszawa-Kraków-Gdańsk, Ossolineum, 1971, 240 pp. Kolbuszewski S.F., Hydronimy battyckie obszaru Pskowszczyzny i Nowogrodczyzny [Baltic hydronyms of the Pskov and Novgorod areas], „Sprawozdania Poznańskiego Towarzystwa Przyjaciół Nauk. Wydział Filologiczno-Filozoficzny”, 1981, 97-99, pp. 259-261. 
LUEV - Lietuvos TSR upiu ir ežeru vardynas [Lexicon of the rivers and lakes of the People's Soviet Republic of Lithuania], Vilnius, Valstybinè politinès ir mokslinès literatūros leidykla, 1963, 228 pp.

Miodowicz K., Wspótczesne koncepcje lokalizacji pierwotnych siedzib Stowian. Dane językoznawcze [Contemporary views on the localization of the primordial homeland of the Slavs. Linguistic data], „Zeszyty Naukowe Uniwersytetu Jagiellońskiego" 722 = „Prace Etnograficzne” 1984, 19, pp. 7-49.

Moszyński K., Pierwotny zasiag języka prasłowiańskiego [The original area of Proto-Slavic], Wrocław-Kraków, Ossolineum, 1957, 332 pp.

Nalepa J., Miejsce uformowania się Prastowiańszczyzny [Place of the formation of the Proto-Slavic people], „Slavica Lundensia” 1973, 1, pp. 55-112.

Ochmański J., Historia Litwy [2. wyd.] [History of Lithuania (2 ${ }^{\text {nd }}$ ed.)], WrocławWarszawa-Kraków-Gdańsk-Lódź, Ossolineum, 1982, 416 pp.

Parczewski M., Stan dyskusji archeologów polskich nad etnogeneza Stowian [The current state of the discussion concerning the ethnogenesis of the Slavs as led by Polish archeologists], [in:] Z polskich studiów slawistycznych. Seria X. Językoznawstwo, Warszawa, Komitet Słowianoznawstwa PAN, 2002, pp. 183-189.

Pluskota T., Nazwy miejscowe ziem ruskich Rzeczypospolitej XVI-XVIII w. Toponimia Ukrainy i pogranicza polsko-ruskiego [Local names of Ruthenian territories of Polish Republic in the $16^{\text {th }}-18^{\text {th }}$ centuries], Bydgoszcz, Wydawnictwo Uczelniane WSP, 1998, $382 \mathrm{pp}$.

Pokorny IEW - J. Pokorny, Indogermanisches etymologisches Wörterbuch [Etymological Dictionary of Indo-European], Bern-München, Francke Verlag, 1959, $1184 \mathrm{pp}$.

Rospond S., Stowiańskie nazwy geograficzne z sufiksem *-bsk- [Slavic geographical names with the suffix *-bsk-], Wrocław-Warszawa-Kraków, Ossolineum, 1969, $434 \mathrm{pp}$.

Rzetelska-Feleszko E., Perspektywy badań nad przedsłowiańskimi nazwami rzecznymi na obszarze Polski [Perspectives of the research on Pre-Slavic river names in the area of Poland], [in:] Hydronimia stowiańska. Materiaty z IX konferencji Komisji Onomastyki Słowiańskiej przy Międzynarodowym Komitecie Slawistów (Mogilany, 16-18 IX 1986 r.) [Slavic hydronomy. Materials from the $9^{\text {th }}$ conference of the Commission of Slavic Onomastics at the International Comittee of Slavists (Mogilany, September the $16^{\text {th }}-18^{\text {th }}, 1986$ )], Wrocław-WarszawaKraków-Gdańsk-Łódź, Ossolineum, 1989, pp. 99-107.

SP II - Stownik prastowiański. II. C-Davbnota [Dictionary of Common Slavic. Part 2: C-Davbnota], Wrocław-Warszawa-Kraków-Gdańsk, Ossolineum, 1976, 368 pp. 
Popowska-Taborska H., Wczesne dzieje Stowian w świetle ich języka [Early history of the Slavs in light of their language], Wrocław, Ossolineum, 1991, $176 \mathrm{pp}$.

Smoczyński W., Pochodzenie litewskiej nazwy miejscowej Pilsūdai (pol. Piłsudy)

[Origin of the Lithuanian place name Pilsūdai (Polish Pitsudy)], „Onomastica” 1982, 29, pp. 115-126.

Vanagas A., Lietuvos TSR hidronimu daryba [Structure of the hydronyms of the People's Soviet Republic of Lithuania], Vilnius, Mintis, 1970, 428 pp.

Vanagas A., Lietuviu hidronimu etimologinis žodynas [Etymological dictionary of Lithuanian hydronyms], Vilnius, Mokslas, 1981, 408 pp.

Vasmer M., Beiträge zur historischen Völkerkunde Osteuropas. I. Die Ostrgrenze der baltischen Stämme [Contributions to the historical ethnography of the Eastern Europe. I. The eastern boundary of the Baltic tribes], "Sitzungsberichte der preussischen Akademie der Wissenschaften. Philosophisch-historische Klasse", Berlin, 1932, pp. 637-666.

WRG - Wörterbuch der russischen Gewässernamen [Dictionary of Russian water names], I-V, Berlin-Wiesbaden, Harrassowitz, 1961-1969.

Ageeva R.A., Gidronimija pskovskih i novgorodskih (Shelonskaja i Derevskaja pjatiny) zemel' $v$ svete istorii zaselenija kraja [Hydronomy of the Pskov and Novgorod areas (Shelonskaya and Derevskaya pyatinas) in the light of the settlement history of the country], Moskva, [a.d.d.], 1974, 20 pp.

Ageeva R.A., Substratnaja gidronimija zapadnoj chasti Kalininskoj oblasti (v granicah istoricheskoj Derevskoj pjatiny) [Substrate hydronomy of the western part of the Kalinin province (within the limits of the historical Derevskaya pyatina)], [in:] Toponimija Central'noj Rossii [Toponymy of Central Russia], Moskva, 1974, Mysl', pp. 104-111.

Ageeva R.A., Gidronimija baltskogo proishozhdenija na territorii pskovskih i novgorodskih zemel' [Hydronomy of Baltic origin in the Pskov and Novgorod areas], [in:] Jetnograficheskie i lingvisticheskie aspekty jetnicheskoj istorii baltov [Ethnographical and linguistic aspects of the ethnic history of the Balts], Riga, Zinatne, 1980, pp. 147-152.

Ageeva R.A., Proishozhdenie imen rek i ozer [Origin of river and lake names], Moskva, Nauka, 1985, 144 pp.

Ageeva R.A., Gidronimija russkogo Severo-Zapada kak istochnik kul'turno-istoricheskoj informacii [Hydronomy of the North-West of Russia as source of cultural and historical information], Moskva, Jeditorial URSS, 2004, 256 pp.

Ark. - G.L. Arkushin, Slovnik mikrotoponimiv i mikrogidronimiv pivnichno-zahidnoï Ukraïni ta sumizhnih zemel'. I-II [Dictionary of the microtoponyms of the North-Eastern Ukraine and contiguous areas. Vols. I-II], Luc'k, Vezha, 20062007, 438 and 536 pp. 
AUM I - Atlas ukraïnskoï movi. I. Polissja, serednja Naddniprjanshchina i sumizhni zemli [Atlas of the Ukrainian language. Part 1: Polesye, middle Dnieper river basin and contiguous areas], Kiïv, Naukova dumka, 1984.

AUM II - Atlas ukraïnskoï movi. II. Volin', Naddnistrjanshchina, Zakarpattja i sumizhni zemli [Atlas of the Ukrainian language. Part 2: Volhynia, Dniester river basin, Transcarpathia and contiguous areas], Kiïv, Naukova dumka, 1988.

Babik Z., Predpolagaemye refleksy pozdnepraslavjanskih foneticheskih izmenenij $v$ substratnoj toponimii lesnoj zony Vostochnoj Evropy [Apparent reflexes of Late Common Slavic sound changes in the substrate toponymy of the forest zone of Eastern Europe], [in:] Prasłowiańszczyzna i jej rozpad [Common Slavic and its disintegration], Warszawa, Energeia, 1998, pp. 177-192.

Bernshtejn S.B., Nekotorye voprosy metodiki izuchenija problem jetnogeneza slavjan [Some methodical problems concerning the study of the Slavic ethnogenesis], [in:] Jetnogenez narodov Balkan i severnogo Prichernomor'ja. Lingvistika, istorija, arheologija [Ethnogenesis of the peoples of the Balkans and of the areas north of the Black Sea. Linguistics, history, archaeology], Moskva, 1984, pp. $11-17$.

Biryla M.V., Belaruskaja antrapanimija. 2. Prozvishchy, utvoranyja ad apeljatyy̆naj leksiki [Byelorussian anthroponymy. 2. Surnames formed from appellative bases], Minsk, Navuka i tjehnika, 1969, 508 pp.

BKB - Blakitnaja kniga Belarusi. Jencyklapedyja [Azure book of Belarus. An encyclopaedy]. Minsk, Belaruskaja Jencyklapedyja,1994, 416 pp.

BM - „Belaruskaja mova” [Byelorussian language], Minsk [a periodical].

Vasil'ev V.L., Drevnebaltijskaja toponimija v regione Novgorodskoj zemli [Old Baltic hydronomy in the Novgrod area], [in:] Novgorod i novgorodskaja zemlja. Istorija $i$ arheologija [Novgorod and its area. History and archaeology], Velikij Novgorod, Novgorodskij gosudarstvennyj ob"edinennyj muzej-zapovednik, 2007, pp. 271-285.

Vasil'ev V.L., O probleme drevnebaltijskogo toponimicheskogo nasledija na russkom Severo-Zapade [On the problem of Baltic toponymic heritage in the NorthWest of Russia], „Voprosy Jazykoznanija” 2008, 3, pp. 76-94.

Vasil'ev V.L., Slavjanskie toponimicheskie drevnosti Novgorodskoj zemli [Slavic toponymical archaisms of the Novgorod area], Moskva, Rukopisnye pamjatniki Drevnej Rusi, 2012, 816 pp.

Vasil'ev V.L., Problematika izuchenija gidronimii baltiskogo proishozhdenija na territorii Rossii [Issues in the study of the hydronomy of Baltic origin in the Russian territory], „Linguistica” 2016, 55, pp. 173-186.

Veselovskij S.B., Onomastikon. Drevnerusskie imena, otchestva, familii [Old Russian names, patronyms and surnames], Moskva, Nauka, 1974, 382 pp. 
Gavrilova T.O., Denisenko Z.M., Slovnik mikrotoponimiv Cherkashchini [Dictionary of microtoponyms of the Cherkassy area], Cherkasi, Ju. Chabanenko, 2010, $494 \mathrm{pp}$.

Dzhakson T.N., Austr i görđum. Drevnerusskie toponimy v drevneskandinavskih istochnikah [Austr í görđum. Old Russian toponyms in Old Scandinavian sources], Moskva, Jazyki slavjanskoj kul'tury, 2001, 208 pp.

Dov1947 - Ukraïns 'ka RSR. Administrativno-teritorial'nij podil na 1 veresnja 1946 roku [Ukrainian People's Soviet Republic. The administrative division for September the $\left.1^{\text {st }}, 1946\right]$, Kiïv, Ukraïns'ke vidavnictvo politichnoï literaturi, 1947, $1064 \mathrm{pp}$.

Zheleznjak I.M., Kï̈vs 'kij toponimikon [Toponymicon of Kiev], Kiïv, Kij, 2014, 224 pp.

Zhuchkevich V.A., Toponimika Belorussii [Toponymy of Belarus], Minsk, Nauka i tehnika, 1968, $182 \mathrm{pp}$.

Zhuchkevich V.A., K voprosu ob uchastii baltov v jetnogeneze belorusov [Towards the problem of participation of the Balts in the ethnogenesis of the Byelorussians], „Sovetskaja Jetnografija” 1968, 1, pp. 107-113.

Zhuchkevich V.A., Kratkij toponimicheskij slovar'Belorussii [Concise dictionary of toponyms of Belarus], Minsk, Izdatel'stvo BGU, 1974, 484 pp.

DABM - Dyjalektalagichny atlas belaruskaj movy [Dialectological atlas of the Byelorussian language], Minsk, Vydavectva Akadjemii navuk BSSR, 1963.

Duridanov I., Problemi na b"lgarskata hidronimija [Problems of Bulgarian hydronomy], [in:] Hydronimia stowiańska. Materiaty z IX konferencji Komisji Onomastyki Słowiańskiej przy Międzynarodowym Komitecie Slawistów (Mogilany, 16-18 IX $1986 r$.) [Slavic hydronomy. Materials from the $9^{\text {th }}$ conference of the Commission of Slavic Onomastics at the International Comittee of Slavists (Mogilany, September the $\left.\left.16^{\text {th }}-18^{\text {th }}, 1986\right)\right]$, Wrocław-Warszawa-Kraków-Gdańsk-Lódź, Ossolineum, 1989, pp. 109-113.

ESLGNPR - Etimologichnij slovnik litopisnih geografichnih nazv Pivdennoï Rusi [Etymological dictionary of the geographical names of southern Rus occurring in the earliest chronicles], Kiïv, Naukova dumka, 1985, 258 pp.

ESUM II - Etimologichnij slovnik ukraïnskoï movi. II. D-Kopci [Etymological dictionary of Ukrainian. Vol. 2. D-Kopci], Kiïv, Naukova dumka 1985, 572 pp.

ESUM VI - Etimologichnij slovnik ukrä̈nskoï movi VI. U-Ja [Etymological dictionary of Ukrainian. Vol. VI. $U-J a]$, Kiïv, Naukova dumka, 2012, 568 pp.

Ivanenko O.V., Nazvi poselen' Sumshchini. Istoriko-etimologichnij slovnik [Names of the localities of the Sumy area. Historical and etymological dictionary], Kiïv, NAN Ukraïni, 2016, 330 pp. 
Katonova E.M., Nekotorye baltijskie gidronimy bassejna Zapadnoj Dviny na territorii Belorussii [Some Baltic hydronyms of the Dvina river basin on the territory of Belarus], „Latvijas TSR Zinātnu Akademijas Vēstis” 1973, 4, pp. 81-87.

Kozlova R.M., Otrazhenie ablauta v slavjanskoj onomastike [Reflexes of the ablaut in the Slavic onomastics], [in:] Studiï z onomastiki ta etimologii [Studies in onomastics and etymology], Kiïv, 2013, pp. 108-142.

Luchik V.V., Etimologichnij slovnik toponimiv Ukraïni. 3700 geografichnih nazv [Etymological dictionary of Ukrainian toponyms. 3700 geographical names], Kiïv, Akademija, 2014, 544 pp.

Mag. - Sloỹnik mikrataponimay̆ Magilëyshchyny [Dictionary of toponyms of the Mogilev area], Magilëy̆, MDU, 2004, 208 pp.

MikrBel - Mikratapanimija Belarusi. Matjeryjaly [Microtoponyms of Belarus. Materials], Minsk, Navuka i tjehnika, 1974, 328 pp.

Neroznak V.P., Nazvanija drevnerusskih gorodov [Names of the Old Russian protocities], Moskva, Nauka, 1983, 208 pp.

NNPRB-B - Nazvy naselenyh punktaỹ Rjespubliki Belarus'. Narmatyy̆ny davednik. Brjesckaja voblasc' [Names of the localities of the Republic of Belarus. Normative hand-book. Brest province], Minsk, Tjehnalogija, 2010, 320 pp.

NNPRB-V - Nazvy naselenyh punktay̆ Rjespubliki Belarus'. Narmatyy̆ny davednik. Vicebskaja voblasc' [Names of the localities of the Republic of Belarus. Normative hand-book. Vitebsk province], Minsk, Tjehnalogija, 2009, 670 pp.

NNPRB-G - Nazvy naselenyh punktay̆ Rjespubliki Belarus'. Narmatyy̆ny davednik. Gomel'skaja voblasc' [Names of the localities of the Republic of Belarus. Normative handbook. Gomel province], Minsk, Tjehnalogija, 2006, 382 pp.

NNPRB-M - Nazvy naselenyh punktay̆ Rjespubliki Belarus'. Narmatyy̆ny davednik. Minskaja voblasc' [Names of the localities of the Republic of Belarus. Normative hand-book. Minsk province], Minsk, Tjehnalogija, 2003, 606 pp.

NNPRB-Mg - Nazvy naselenyh punktay̆ Rjespubliki Belarus'. Narmatyy̆ny davednik. Magilëyskaja voblasc' [Names of the localities of the Republic of Belarus. Normative hand-book. Mogilev province], Minsk, Tjehnalogija, 2007, 408 pp.

Pavl. - S. Pavlenko, Mikrotoponimi Chernigovo-Sivershhini [Microtoponyms of the Chernigov and Novgorod-Siverskyj areas], Chernigiv, PVK Desna, 2013, 600 pp.

Rogalev A.F., Toponimija Belarusi. Gomelskaja oblast'. Loevskij rajon [Byelorussian toponymy. Homel province. Loev region], Gomel', GGU, 2015, 318 pp.

SGU - Slovnik gidronimiv Ukraïni [Dictionary of hydronyms of the Ukraine], Kiïv, Naukova dumka, 1979, 782 pp.

Sedov V.V., Slavjane Verhnego Podneprov'ja i Podvin'ja [Slavs of the Upper Dnieper and Dvina river basins], Moskva, Nauka, 1970, 200 pp. 
Sedov V.V., Gidronimija goljadi [Golyad' hydronomy], [in:] Pitannja gidronimiki [Current issues of hydronomy], Kiïv, 1971, pp. 131-137.

Sedov V.V., Baltskaja gidronimika Volgo-Okskogo mezhdurech'ja [Baltic hydronomy between Volga and Oka], [in:] Drevnee poselenie v Podmoskov'e [Ancient settlement in the Moscow area], Moskva, 1971, pp. 108-113.

Sedov V.V., Vostochnye slavjane $v$ VI-XIII $v$. [Eastern Slavs in the $6^{\text {th }}-13^{\text {th }}$ centuries], Moskva, Nauka, 1982, 328 pp.

Smol. - G.P. Smolickaja, Gidronimija bassejna Oki. Spisok rek i ozer [Hydronomy of the Oka river basin. A repertory of rivers and lakes], Moskva, Nauka, 1976, $404 \mathrm{pp}$.

Spis1902 - Spisok" naselennyh" mrst" Chernigovskoj gubernii, imrjushhih" ne menre 10 zhitelej, po dannym "za 1901 god" [Repertory of localities of the Gouvernment of Chernigov having at least 10 inhabitants, according to the data for the year 1901], Chernigov", Tip. gub. pravlenija, 1902, 188 pp.

Tolstoj N.I., O neposledovatel'nosti pervoj palatalizacii zadnenebnyh soglasnyh $v$ slavjanskih jazykah. III [Some exceptions to the first palatalization of velars in the Slavic languages], [in:] Slawistyczne studia językoznawcze [Linguistic studies in Slavic languages], Wrocław-Warszawa-Kraków-Gdańsk-Łódź, Ossolineum, 1987, pp. 407-410.

Toporov V.N., Baltica Podmoskov'ja [Baltica of the vicinities of Moscow], [in:] Balto-slavjanskij sbornik [Balto-Slavic collection], Moskva, 1972, pp. 217-280.

Toporov V.N., Drevnjaja Moskva v baltijskoj perspektive [Old Moscow in a Baltic perspective], „Balto-slavjanskie issledovanija 1981” 1982, pp. 3-81.

Toporov V.N., Baltijskij gorizont drevnej Moskvy [Baltic horizon of the Old Moscow], „Acta Baltico-Slavica” 1982, 14, pp. 259-272.

Toporov V.N., Baltijskij jelement v gidronimii Pooch'ja. I. A. Verhnee levoberezhnoe Pooch'e [Baltic element in the hydronomy of the Oka river basin. I. Left bank of the Upper Oka], „Balto-slavjanskie issledovanija 1986” 1988, pp. 154-177.

Toporov V.N., Baltijskij jelement v gidronimii Pooch'ja. II [Baltic element in the hydronomy of the Oka river basin. II.], „Balto-slavjanskie issledovanija 1987” 1989, pp. 47-69.

Toporov V.N., Iz baltijskoj areal'noj gidronimii. K latgal'sko-vostochnoslavjanskim jazykovym svjazjam [From the Baltic areal hydronomy. Towards East Slavic-Latgalian language contacts], [in:] Batto-stowiańskie związki językowe [Balto-Slavic language contacts], Wrocław-Warszawa-Kraków, 1990, pp. 365-380.

Toporov V.N., O baltijskoj gidronimii Verhnego Podon'ja [On Baltic hydronomy of the Upper Don river basin], „Linguistica Baltica” 1992, 1, pp. 225-240.

Toporov V.N., Baltijskij jelement v gidronimii Pooch'ja. III, I. A. Verhnee levoberezhnoe Pooch'e. I. Levye pritoki Oki [Baltic element in the hydronomy of the Oka 
river basin. I. A. Left bank of the Upper Oka. I. Left tributaries of the Oka], „Balto-slavjanskie issledovanija 1988-1996" 1997, pp. 276-310.

Trubachev O.N., Nazvanija rek pravoberezhnoj Ukrainy. Jetimologija, slovoobrazovanie, jetnicheskaja interpretacija [River names of Western Ukraine. Etymology, formation, ethnic interpretation], Moskva, Nauka, 1968, 292 pp.

TT - V.N. Toporov, O.N. Trubachev, Lingvisticheskij analiz gidronimov Verhnego Podneprov'ja [Linguistic analysis of the hydronyms of the Upper Dnieper basin], Moskva, Nauka, 1962, 272 pp.

Horoshkevich A.L., Sud'ba - arheologija. Issledovateli slavjanskoj istorii Irina Petrovna Rusanova i Boris Anisimovich Timoshhuk [Fate - Archaeology. The investigators of Slavic history Irina Petrovna Rusanova and Boris Anisimovich Timoshhuk], ,Slavia Antiqua” 2000, 41, pp. 191-210.

Cherepanova E.A., Narodnaja geograficheskaja terminologija Chernigovsko-Sumskogo Poles'ja [Folk geographical terminology of the Chernigov and Sumy Polesye], Sumy, Sumskij GPI, 1984, 276 pp.

Shul'gach V.P., Praslov'jans'kij gidronimnij fond (fragment rekonstrukcii) [Common Slavic hydronomic fund (fragment of a reconstruction)], Kiïv, NAN Ukraïni, 1998, $382 \mathrm{pp}$.

Jarotov A.E., Toponimika Belarusi. Kurs lekcij [Toponymy of Belarus. Course of lectures], Minsk, BGU, 2011, 44 pp.

Jashkin I.Ja., Belaruskija geagrafichnyja nazvy. Tapagrafija, gidralogija [Byelorussian geographical terms. Topography, hydrology], Minsk, Navuka i tjehnika, 1971, 256 pp. 